\title{
ARMONIZACIÓN DE LA TÉCNICA MONITORIA EN EUROPA. EL PROCESO MONITORIO EUROPEO COMO PUNTO DE PARTIDA*
}

\section{HARMONIZATION OF THE ORDER PAYMENT PROCEDURE. THE EUROPEAN ORDER FOR PAYMENT PROCEDURE AS A STARTING POINT}

\author{
Felip Alba Cladera \\ Profesor Ayudante de Derecho Procesal \\ Universidad de las Islas Baleares
}

Recibido: 21.06.2020 / Aceptado: 01.07.2020

DOI: https://doi.org/10.20318/cdt.2020.5670

\begin{abstract}
Resumen: El presente trabajo se cuestiona si tiene sentido que el proceso monitorio europeo siga limitando su ámbito de aplicación a asuntos transfronterizos. El análisis de los puntos de convergencia y divergencia entre el proceso monitorio europeo y otros monitorios nacionales -particularmente, el español- muestra que el proceso monitorio europeo podría constituir la base para una armonización de la técnica monitoria a nivel europeo. Al mismo tiempo, y teniendo en cuenta que la armonización exige una legislación lo más perfecta posible, se formulan propuestas para dar solución a algunas deficiencias que se han detectado en la aplicación del proceso monitorio europeo.

Palabras clave: Derecho Procesal Civil Europeo, requerimiento europeo de pago, armonización, ámbito de aplicación, notificación, control de oficio de cláusulas abusivas.

Abstract: This paper questions whether it makes sense that the European order for payment procedure continues to limit its scope to cross-border cases. The analysis of the points of convergence and divergence between the European order for payment procedure and other national orders for payment procedures - particularly the Spanish - shows that the European order for payment procedure might constitute the basis for a harmonization of the order for payment procedure at European level. At the same time, and taking into account that harmonization requires the most perfect legislation possible, proposals are made to solve some deficiencies that have been detected in the application of the European order for payment procedure.
\end{abstract}

Keywords: European Civil Procedural Law, european order for payment, harmonisation, scope, service, ex officio control of unfair terms.

Sumario: I. Antecedentes. II. A vueltas con el art. 81 TFUE. III. ¿Por qué el monitorio? IV. Convergencia de los procesos monitorios en Europa. Del europeo al nacional, un camino de ida y vuelta. 1. Sin límite de cuantía. 2. Potestad del órgano jurisdiccional de formular una propuesta de requerimiento de pago por importe inferior al peticionado. 3. Control de cláusulas abusivas. V. Algu-

\footnotetext{
* Trabajo realizado en el marco del Proyecto de Investigación «Hacia un proceso civil convergente con Europa. Hitos presentes y retos futuros» (PGC2018-094693-B-100), financiando por el Ministerio de Ciencia, Innovación y Universidades y dirigido por los Profs. Gascón Inchausti y Peiteado Mariscal.
} 
nas propuestas de modificación del RPME (para facilitar la extensión de su ámbito de aplicación). 1. ¿Nos conviene un proceso monitorio europeo documental? 2. Reconsideración de la notificación del requerimiento europeo de pago. A) La notificación del requerimiento europeo de pago. Statu quo. B) Comparación con la notificación de requerimientos de pago nacionales. C) Conclusiones. 3. El cauce de revisión en casos excepcionales del art. 20. 4. Lenguas aceptables en el Estado miembro de ejecución. VI. Consideraciones finales.

\section{Antecedentes}

1. La voluntad de establecer un proceso monitorio europeo no es, ni mucho menos, nueva - y, también, muy anterior a la promulgación del Reglamento (CE) nº 1896/2006 del Parlamento Europeo y del Consejo, de 12 de diciembre de 2006, por el que se establece un proceso monitorio europeo (RPME, en lo sucesivo) - . Así, el Consejo de Europa, en 1981, en una recomendación sobre medidas para facilitar el acceso a la justicia, propugnaba la adopción de «disposiciones en materia de deudas no impugnadas o exigibles que aseguren la obtención rápida de una resolución definitiva sin formalidades, comparecencias ni costes innecesarios» ${ }^{1}$.

2. El conocido como «Proyecto Storme», titulado Aproximación del derecho procesal en la Unión Europea ${ }^{2}$, formuló un proyecto de directiva a través de la cual se pretendía armonizar ciertos elementos del proceso civil. Esta propuesta prestaba particular atención al proceso monitorio, lo que no pasó desapercibido al legislador europeo cuando proyectó la creación de un proceso monitorio a nivel europeo $^{3}$. El Tratado de Ámsterdam, firmado en 1997 y que entró en vigor en el 1999, comunitarizó la cooperación en materia judicial civil; de abordar esta materia a través de convenios multilaterales cerrados se pasó a regularla a través de Derecho de la Unión Europea propiamente dicho (reglamentos y directivas $)^{4}$. El objetivo era crear un espacio de libertad, seguridad y justicia, adoptando, en particular, medidas relativas a la cooperación judicial en materia civil.

3. Las conclusiones del Consejo Europeo de Tampere celebrado el 15 y 16 de octubre, en lo referido a la búsqueda de un mejor acceso a la justicia en Europa, abogaron por la creación de normas procesales comunes para dar un tratamiento simplificado y acelerado a los litigios de menor cuantía y a las reclamaciones sin oposición ${ }^{5}$, lo que debería ir acompañado, además, de la supresión de los procedimientos intermedios o de exequatur para que fueran reconocidas y ejecutables automáticamente en toda la UE las resoluciones resultantes de estos tipos de litigios ${ }^{6}$.

4. La Directiva 2000/35 CE del Parlamento Europeo y del Consejo, de 29 de junio de 2000, por la que se establecían medidas de lucha contra la morosidad en las operaciones comerciales, incluía una referencia velada a los procedimientos monitorios proclamando que la previsión de perjuicios para el moroso solo tendría carácter disuasorio si el Derecho sustantivo va de la mano del procesal, es decir, si se acompaña de procedimientos de reclamación rápidos y eficaces para el acreedor ${ }^{7}$. Si bien se dejaba claro que no se exigía a los Estados miembros la adopción de un procedimiento específico de cobro de

\footnotetext{
${ }^{1}$ Recomendación $n^{\circ} \mathrm{R}$ (81) 7 sobre medidas que facilitan el acceso a la justicia, de 14.5.1981, apartado c, punto 9.

2 M. Storme, Approximation of judiciary law in the European Union, Kluwer, Dordrecht, 1994. Ésta podría calificarse como la primera gran propuesta verdaderamente ambiciosa en cuanto a armonización procesal europea se refiere.

${ }^{3}$ Así, en el Libro verde sobre el proceso monitorio europeo y las medidas para simplificar y acelerar los litigios de escasa cuantía, Bruselas, 20.12.2002, $\operatorname{COM(2002)746~final,~p.~13,~se~hizo~eco~del~trabajo~liderado~por~el~profesor~Storme.~}$

${ }^{4} \mathrm{Vid}$. art. 65 del Tratado constitutivo de la Comunidad Europea (actual art. 81 TFUE).

${ }^{5}$ Conclusión 30

${ }^{6}$ Conclusión 34.

${ }^{7}$ Considerando 20. Añadiendo, además, que de conformidad con el principio de no discriminación establecido en el artículo 12 del Tratado constitutivo de la Comunidad Europea (actual art. 19 TCE), tales procedimientos debían estar a disposición de todos los acreedores establecidos en la CE.
} 
créditos no impugnados ${ }^{8}$, sí que se disponía que los Estados miembros debian velar para que se pudiera obtener un titulo ejecutivo, independientemente del importe de la deuda, normalmente en un plazo de 90 dias naturales a partir de la presentación de la demanda o de la solicitud por parte del acreedor ante el Tribunal u otra autoridad competente, siempre que no hubiera habido impugnación de la deuda o de cuestiones del procedimiento (art. 5).

5. Tanto la propuesta de Reglamento por el que se establece un proceso monitorio europeo ${ }^{9}$ como la del Reglamento por el que se establece un proceso europeo de escasa cuantía ${ }^{10}$ presentadas por la Comisión planteaban un ámbito de aplicación distinto al que finalmente entró en vigor. Como bien sabemos, estos procesos europeos se aplican únicamente a asuntos transfronterizos, entendidos éstos como aquellos en los que al menos una de las partes esté domiciliada o tenga su residencia habitual en un Estado miembro distinto al del órgano jurisdiccional que conozca el proceso ${ }^{11}$. Ambos procesos, además, tienen carácter complementario y opcional con respecto a sus homólogos nacionales ${ }^{12}$, por lo que no substituyen a estos últimos; así, el demandante, por ejemplo, aunque el demandado estuviera domiciliado en otro estado miembro, podría recurrir al proceso monitorio nacional o al proceso declarativo ordinario correspondiente y, si obtuviera una resolución favorable, solicitar certificarla como título ejecutivo europeo -siempre que se hubieren cumplido los requisitos- o ejecutarla al amparo del RB I bis -con las desventajas que ello conlleva-.

\section{A vueltas con el art. 81 TFUE}

6. En sendas propuestas, si bien contemplaban este carácter complementario y opcional ${ }^{13}$, estos procesos europeos uniformes extendían su ámbito de aplicación más allá de los litigios transfronterizos $^{14}$. La Comisión optaba por una interpretación amplia del artículo 65 del Tratado constitutivo de la Comunidad Europea, ahora art. 81 del Tratado de Funcionamiento de la Unión Europea (TFUE, en lo sucesivo) distinta a la imperante. Según este precepto, la acción legislativa europea en el ámbito de la cooperación judicial en materia civil se circunscribirá a asuntos civiles con repercusión transfronteriza en cuanto resulte necesario para el buen funcionamiento del mercado interior. Como la tesis vencedora es la que concibe la repercusión transfronteriza como equivalente a litigio transfronterizo - entendiendo éste como aquel en el que al menos una de las partes esté domiciliada o tenga su residencia habitual en un EM distinto al del órgano jurisdiccional que conozca el proceso- - y, por lo tanto, es la que impide dar un paso más, mostraremos las inconsistencias de ésta y las consistencias de la otra, la que propugnó la Comisión cuando planteó dichas propuestas.

7. La competencia legislativa del Parlamento y el Consejo en materia de cooperación judicial en materia civil viene regulada por el art. 81 TFUE. Y, desde luego, la ambigüedad de este es considerable,

${ }^{8}$ Considerando 23.

9 Bruselas, 25.05.2004, COM (2004)173 final/3.

${ }^{10}$ Bruselas, 15.3.2005, COM (2005) 87 final.

${ }^{11}$ Cfr. arts. 2 y 3 RPME con el art. 2 de la Propuesta de RPME y los arts. 2 y 3 del Reglamento (CE) nº 861/2007 del Parlamento Europeo y del Consejo, de 11 de julio de 2007, por el que se establece un proceso europeo de escasa cuantía (RPEEC, en lo sucesivo) con el art. 2 de la Propuesta de RPEEC.

12 Considerando 10 del RPME y considerando 8 del RPEEC.

13 Considerando 8 de la propuesta de RPME y considerando 7 de la propuesta de RPEEC.

${ }^{14}$ El Comité Económico y Social Europeo consideraba que el proceso monitorio europeo no debía tener carácter complementario, sino que debía ser el único que existiera. Vid. Dictamen del Comité Económico y Social Europeo sobre la «Propuesta de Reglamento del Parlamento Europeo y del Consejo por el que se establece un proceso monitorio europeo» (COM(2004) 173 final/3 - 2004/0055 (COD)), epígrafe 4.9.1: «...sólo deberá existir un proceso monitorio: el que está previsto y regulado por la propuesta de Reglamento que se examina, el cual, por definición, no podrá dejar de ser considerado como el más adecuado a las situaciones a las que se aplica, so pena de perder legitimidad. Por esta razón, con la adopción del Reglamento, deberán desaparecer los procesos monitorios previstos en algunas legislaciones nacionales de los Estados miembros»». 
tanta que puede amparar una tesis y la contraria $-\mathrm{y}$ todo ello sin forzar sus costuras — ${ }^{15}$. El apartado primero de este precepto dice así: «la Unión desarrollará una cooperación judicial en asuntos civiles con repercusión transfronteriza, basada en el principio de reconocimiento mutuo de las resoluciones judiciales y extrajudiciales. Esta cooperación podrá incluir la adopción de medidas de aproximación de las disposiciones legales y reglamentarias de los Estados miembros». ¿Si no se hubiera querido legitimar una posibilidad de mayor armonización, no diría, simplemente, asuntos civiles transfronterizos en vez de «con repercusión transfronteriza»? A esto se añade que, acto seguido, en su apartado segundo se dispone que, a los efectos del apartado primero y «cuando resulte necesario para el buen funcionamiento del mercado interior», podrán tomarse medidas legislativas para garantizar «una tutela judicial efectiva» o eliminar «los obstáculos al buen funcionamiento de los procedimientos civiles, fomentando si es necesario la compatibilidad de las normas de procedimiento civil aplicables en los Estados miembros».

8. Si recurrimos a la comparación con el artículo referido a las competencias normativas en cooperación judicial en materia penal ${ }^{16}$, es cierto que éste, en vez del "podrá incluir", dice así: «la cooperación judicial en materia penal...incluye la aproximación de las disposiciones legales y reglamentarias de los Estados miembros...» (art. 82.1 TFUE) ${ }^{17}$. Si bien la versión civil es más atenuada en comparación con la penal, no se puede deducir que en la primera la puerta a la armonización más allá de los asuntos transfronterizos esté cerrada. Siguiendo con la comparativa, el apartado segundo del art. 82 TFUE reza lo siguiente: «en la medida en que sea necesario para facilitar el reconocimiento mutuo de las sentencias y resoluciones judiciales y la cooperación policial y judicial en asuntos penales con dimensión transfronteriza, el Parlamento Europeo y el Consejo podrán establecer normas mínimas mediante directivas adoptadas con arreglo al procedimiento legislativo ordinario». Y sin que sea ni mucho menos concluyente entrar en disquisiciones semánticas, queremos apuntar que, en todo caso, el término dimensión abarca menos que el de repercusión, pues la dimensión transfronteriza se tiene o no se tiene, pero que un asunto tenga repercusiones transfronterizas no supone ni mucho menos que el asunto sea transfronterizo ${ }^{18}$.

9. ¿Un sistema procesal nacional ineficiente de cobro de deudas no puede tener repercusión transfronteriza y afectar al buen funcionamiento del mercado interior ${ }^{19}$ La Comisión, incluso, adujo -

${ }^{15}$ F. GASCÓn InCHAUSTI, en Derecho europeo y legislación procesal civil nacional: entre autonomía y armonización, Marcial Pons, Madrid, 2018, p. 65, apunta, al respecto, que «se trata de unas previsiones tal vez vagas e imprecisas, pero con un potencial expansivo indudable».

${ }^{16}$ Cfr. M. Requejo Isidro, «Do We Need Harmonisation to Achieve Harmonious Cooperation? Judicial Cooperation for Criminal Matters as a Testing Field», en B. Hess y X. E. Kramer (eds.), From common rules to best practices in European Civil Procedure, Nomos, Baden-Baden, 2017, pp. 106 a 118.

${ }^{17}$ En la versión en inglés el may frente al shall.

${ }_{18}$ Vid. las definiciones de los respectivos términos en el Diccionario de la lengua española (Real Academia Española):

Dimensión:1. f. Aspecto o faceta de algo.; 2. f. Medida de una magnitud en una determinada dirección. Las dimensiones del salón. U. t. en sent. fig. Un escándalo de grandes dimensiones.; 3. f. Fís. Cada una de las magnitudes que fijan la posición de un punto en un espacio. Una superficie tiene dos dimensiones: el largo y el ancho.; 4.f. Fís. Cada una de las magnitudes fundamentales, tiempo, longitud, masa y cargaeléctrica, con que se expresa una variable física.; 5 . f. Mús. Medida de los compases.

Repercusión: 1. f. Acción y efecto de repercutir.; 2. f. Circunstancia de tener mucha resonancia algo.

Repercutir:1. intr. rebotar (\| retroceder o cambiar de dirección).; 2. intr. reverberar.; 3. intr. Dicho del sonido: Producir eco.; 4. intr. Dicho de una cosa: Trascender, causar efecto en otra.; 5. tr. Hacer que un impuesto, un coste, etc., recaiga o tenga efecto sobre otra persona distinta de la que lo paga inicialmente; 6 . tr. Med. desus. Rechazar, repeler, hacer que un líquido corporal retroceda o refluya hacia atrás.

Si confrontamos, también, dimension frente implication llegamos a la misma conclusión.

19 Así, la propuesta de RPME, p. 8, planteaba el siguiente ejemplo: «Dos empresas que compitan en un mismo Estado miembro, de las cuales sólo una esté domiciliada en ese Estado miembro, no estarán en igualdad de condiciones si únicamente la que esté domiciliada en el extranjero puede recurrir a un proceso monitorio europeo eficaz. De la misma manera, una empresa cuyos clientes residan en su mayoría en el extranjero gozaría de una ventaja considerable al poder acceder a ese proceso, con respecto a una empresa competidora domiciliada en el mismo Estado miembro que desarrollara la mayor parte de su actividad empresarial en el mismo país. Por otra parte, y especialmente en el caso de los Estados miembros que no ofrecen ningún instrumento eficaz para el cobro de deudas no impugnadas, resultaría políticamente difícil explicar tanto a los acreedores como a los deudores por qué tienen acceso o están sujetos a un mecanismo más eficaz si el caso es transfronterizo que si es interno». En la misma línea, vid. la propuesta de RPEEC, pp. 5, 6 y 7. 
sin rubor alguno- que la eficacia de los procesos de los distintos Estados miembros para la tutela judicial del crédito era muy dispar entre ellos, que unos países tenían "procesos eficaces y racionales» mientras que otros no, lo que distorsionaba la competencia y alteraba el buen funcionamiento del mercado interior $^{20}$. Tal argumento, aunque puede ser válido, para adoptarlo hay que ser extremadamente precavido, ya que conviene tener presente que la armonización, si bien puede implicar una mejora del nivel de algunos procesos, también puede empeorar el de otros; de ahí que creamos que sea razonable, ante una eventual extensión del ámbito de aplicación del proceso monitorio europeo, mantener, al menos en una primera fase, su carácter opcional y complementario con respecto a los diversos procesos nacionales.

10. Además, lo interno puede devenir transfronterizo con suma facilidad: litigio puramente interno cuya resolución final debe ejecutarse en otro Estado miembro. Así, la propuesta inicial de proceso monitorio europeo ahondaba en esta línea con otros ejemplos más ingeniosos ${ }^{21}$.

11. Una vez que se confirma que la UE tiene la competencia normativa atribuida, debe ejercer ésta conforme al principio de subsidiariedad y proporcionalidad (art. 5.3 TUE). El establecimiento de un proceso europeo más allá de los asuntos estrictamente transfronterizos, creemos, podría sortear sin grandes esfuerzos argumentales las exigencias derivadas de dichos principios. La UE solo debe desarrollar su acción legislativa con respecto a una materia cuando a los Estados miembros por sí solos no les sea posible alcanzar los objetivos perseguidos. Un proceso uniforme a nivel europeo es obvio que solo puede lograrse a través de un instrumento legislativo comunitario. $Y$ en cuanto al respeto del principio de proporcionalidad, la regulación se limitaría «a lo estrictamente necesario» para alcanzar dicho proceso; además, cualquier óbice al respecto se superaría con el carácter opcional del proceso monitorio europeo $^{22}$. Teniendo presente, también, que todo lo que no esté regulado por el reglamento, para no ir más allá de lo estrictamente necesario, se deja en manos de las respectivas legislaciones nacionales. ${ }^{23}$.

\section{III. ¿Por qué el monitorio?}

12. La armonización europea de un procedimiento común ${ }^{24}$ —entendido éste como aquel proceso cuyo objeto abarca cualquier tipo de pretensión, salvo las excepciones legales que establezcan otra tramitación específica - es, ahora mismo, poco realista ${ }^{25}$. Aunque se planteara con carácter alternativo, es decir, opcional frente a los procesos nacionales, tal vez, los propios litigantes serían reacios a utilizarlo.

13. Como creemos que lo mejor es ir paso a paso, abogamos por probar, primeramente, con el proceso monitorio europeo. Aunque el proceso europeo de escasa cuantía, valga la redundancia, sea

\footnotetext{
${ }^{20}$ Si bien lo hizo en la propuesta de RPEEC, pp. 5, 6 y 7, creemos que son extrapolables a la discusión sobre el proceso monitorio europeo.

${ }^{21}$ «Pongamos por caso que dos personas domiciliadas en Francia tengan un accidente de coche en Alemania y litiguen por daños y perjuicios ante un tribunal francés. ¿Es éste un caso exclusivamente interno, por encontrarse ambas partes y el tribunal en el mismo Estado miembro, o trasciende del ámbito nacional al existir una relación con otro Estado miembro cuyos tribunales serían competentes para ver la causa si el demandante hubiera preferido ejercitar su acción en este país? Optar por la primera alternativa equivale a decidir el carácter transfronterizo de una causa sobre la base de la elección subjetiva del demandante; en función del tribunal al que éste decida recurrir, una misma situación tendrá una dimensión internacional o será exclusivamente de ámbito nacional, a pesar de que en algunos aspectos esté vinculada a dos Estados miembros. Podría plantearse que todos los casos en los que existen factores de relación con varios Estados miembros tienen implicaciones transfronterizas. Pero, en primer lugar, resultaría inevitablemente complicado definir en qué consiste un factor de relación suficiente. ¿Debe considerarse suficiente para establecer ese vínculo el hecho de que el Derecho sustantivo de un Estado miembro distinto del Estado del foro sea aplicable?», pp. 7 y 8.

22 Vid. las propuestas de RPME, pp. 8 y 9, y RPEEC, p. 7.

${ }^{23}$ Art. 21 y 26 RPME y, en el mismo sentido, art. 19 RPEEC.

${ }^{24}$ Siguiendo la terminología usada por M. Ortells, Derecho Procesal Civil, Ed. 17ª , Aranzadi, Navarra, 2018, pp. 469 y 470. En la LEC, en cambio, se utiliza el término procesos declarativos (vid. Libro II y art. 248; juicio ordinario y juicio verbal).

${ }_{25}$ Resolución del Parlamento Europeo, de 4 de julio de 2017, con recomendaciones destinadas a la Comisión sobre normas mínimas comunes del proceso civil en la Unión, que incluía una propuesta de directiva, la cual, por ahora, no ha prosperado.
} 
un proceso para reclamar deudas dinerarias de escasa cuantía y, si se quiere, simplificado, no hay duda alguna que el proceso más simple es el monitorio; simplicidad que implica más puntos en común y menos divergencias con los procesos homólogos de los diversos países y que, por lo tanto, las respectivas legislaciones procesales y prácticas forenses nacionales podrían adoptarlo de forma poco traumática.

14. La técnica monitoria, apuntándolo de forma muy general, sigue el siguiente esquema. Primeramente, el acreedor formula una petición de requerimiento de pago ante un órgano jurisdiccional, y si se cumplen los requisitos para su admisión se emite dicho requerimiento de pago notificándose éste al deudor. A partir de ahí, todo depende de la actitud del deudor: puede pagar; permanecer inactivo y se despachará ejecución contra él; o si formula oposición — sin tener que motivarla en este estadio - la controversia se dilucida según el proceso ordinario que corresponda. Si bien un monitorio es un proceso especial que tiene naturaleza declarativa, la contradicción es inexistente - al menos, si el deudor paga o permanece pasivo-, lo que conlleva que ante una eventual armonización o uniformización del proceso monitorio a nivel europeo las distintas legislaciones nacionales procesales no sufrirían ningún terremoto de magnitudes considerables (no habría armonización en cuestiones como prueba y alegación, por ejemplo). La contradicción se restaura con la oposición del deudor y a partir de ahí ya se sigue un procedimiento ordinario - que sería el que correspondería en cada Estado miembro o, si es aplicable y el demandante opta por éste, el proceso europeo de escasa cuantía ${ }^{26}$ - Es decir, desde una visión de conjunto, la armonización solo se produciría para aquellos supuestos en los que el demandado paga o permanece inactivo, ya que si hay oposición el litigio continua a través del proceso ordinario nacional que corresponda. En el caso español, por ejemplo, ¿qué sería más traumático para nuestro ordenamiento jurídico procesal? ¿sustituir nuestro proceso monitorio por el europeo o que todos los litigios de reclamación de cantidad que caen bajo el ámbito del juicio verbal por razón de la cuantía se dilucidaran por el proceso europeo de escasa cuantía?

\section{Convergencia de los procesos monitorios en Europa. Del europeo al nacional, un camino de ida y vuelta}

\section{Sin límite de cuantía}

15. La LEC del 2000, en su origen, limitaba a cinco millones de pesetas la cuantía de las deudas que podían reclamarse a través del proceso monitorio, cuantía que con la llegada del euro se transformó en su equivalente, 30.000 euros. Dicho umbral de cuantía se elevó hasta los 250.000 euros mediante la Ley $13 / 2009$, de 3 de noviembre, de reforma de la legislación procesal para la implantación de la nueva Oficina judicial ${ }^{27}$. En la exposición de motivos de dicha ley se adujo que la elevación de la cuantía de los créditos exigibles a través del proceso monitorio continuaba «la estela de prudencia iniciada por el legislador de la Ley de Enjuiciamiento Civil 1/2000, de 7 de enero, en el sentido de que no se suprime el límite cuantitativo para las pretensiones que se hacen valer por este procedimiento», si bien se reconoció, al mismo tiempo, que ésta no era la línea seguida a nivel europeo, citando como ejemplo el proceso monitorio europeo.

16. La resistencia a la eliminación del límite de cuantía duró un brevísimo lapso, ya que la Ley 37/2011, de medidas de agilización procesal, suprimió límite alguno a imagen y semejanza - como

${ }^{26}$ Posibilidad que incluyó expresamente el RPME a través de la reforma de su art. 17 introducida por el Reglamento (UE) 2015/2421; así, ante un eventual escrito de oposición, el demandante puede, si éste es aplicable, optar porque el proceso continúe a través del proceso europeo de escasa cuantía.

${ }^{27}$ Ya durante la tramitación parlamentaria, el Grupo Popular presentó una enmienda que, en su versión inicial, pretendía la eliminación de límite de cuantía alguno. Vid., con más profundidad, S. ArAgoneses, «La reforma del Libro IV de la ley de Enjuciamiento civil: de los procesos especiales», en Guía práctica de la nueva Oficina judicial (coord. J. BanAcloche PaLAo), Las Rozas, 2010, p. 388. 
reconoce el propio preámbulo- del proceso monitorio europeo. Así, en el proceso monitorio español pueden reclamarse deudas dinerarias de cualquier importe, mientras éstas sean líquidas, determinadas, vencidas y exigibles (art. 812 LEC).

\section{Potestad del órgano jurisdiccional de formular una propuesta de requerimiento de pago por importe inferior al peticionado}

17. Otra muestra de convergencia entre el proceso monitorio español y el europeo es que el legislador español, a través de la Ley 4/2011, tomando como referencia el art. 10 RPME, introdujo la posibilidad de que el juez propusiera al demandante la emisión de un requerimiento por cuantía inferior a la que se había solicitado. Convergencia que se explica, sin tapujos, en el propio Preámbulo de dicha ley: «como se ha apuntado, los procesos europeos monitorio y de escasa cuantía tienen aplicación únicamente en litigios transfronterizos. Sin embargo, el hecho de que algunas normas sean más ventajosas que las que incluye nuestra legislación obliga a introducir aquellos cambios que confieran el mismo tratamiento procesal a cualquier acreedor, resida en España o en otro país de la Unión Europea».

\section{Control de cláusulas abusivas}

18. La STJUE de 14 de junio de 2012, Banco Español de Crédito, asunto C-618/10, declaró que la configuración del proceso monitorio español se oponía a la Directiva 93/13/CE del Consejo, de 5 de abril de 1993, sobre las cláusulas abusivas en los contratos con los consumidores, en la medida en «que no permite que el juez que conoce de una demanda en un proceso monitorio, aun cuando disponga de los elementos de hecho y de Derecho necesarios al efecto, examine de oficio - in limine litis ni en ninguna fase del procedimiento- el carácter abusivo de una cláusula sobre intereses de demora contenida en un contrato celebrado entre un profesional y un consumidor, cuando este último no haya formulado oposición ${ }^{28}$. El Derecho procesal español concebía que el control de las cláusulas abusivas debía dilucidarse, previa oposición del deudor al requerimiento de pago, en el ulterior proceso declarativo; lo cual no fue de agrado del TJUE ${ }^{29}$, sosteniendo, así, que concurría «un riesgo no desdeñable de que los consumidores afectados no formulen la oposición requerida, ya sea debido al plazo particularmente breve previsto para ello, ya sea porque los costes que implica la acción judicial en relación con la cuantía de la deuda litigiosa puedan disuadirlos de defenderse, ya sea porque ignoran sus derechos o no perciben cabalmente la amplitud de los mismos, o ya sea debido, por último, al contenido limitado de la demanda presentada por los profesionales en el proceso monitorio y, por ende, al carácter incompleto de la información de que disponen $»^{30}$. Así, el TJUE consideró que de esta forma «bastaría con que los profesionales presentaran la demanda en un proceso monitorio en lugar de hacerlo en el juicio civil ordinario para privar a los consu-

\footnotetext{
${ }^{28}$ Apartado 57.

${ }^{29}$ Cuando en las conclusiones de la Abogada General del asunto C-618/10, Banco Español, presentadas el 14 de febrero de 2012, avalaba la concepción española: «La Directiva 93/13/CEE del Consejo, de 5 de abril de 1993, sobre las cláusulas abusivas en los contratos celebrados con consumidores, debe interpretarse en el sentido de que no obliga a un órgano jurisdiccional nacional a pronunciarse de oficio y ab limine litis en un proceso monitorio nacional sobre el carácter no vinculante de una cláusula de intereses de demora incluida en un contrato de crédito al consumo, siempre que el examen del posible carácter abusivo de dicha cláusula pueda, en virtud del Derecho procesal nacional, trasladarse a un procedimiento contencioso que se inicie mediante recurso del deudor en el cual el órgano jurisdiccional nacional tenga la posibilidad de reunir los elementos de hecho y de Derecho necesarios para llevar a cabo tal apreciación». La Abogado General consideraba que los Estados miembros no están obligados por el Derecho de la Unión a establecer en sus ordenamientos jurídicos nacionales un examen de oficio y in limine litis del carácter abusivo de las cláusulas contractuales en el proceso monitorio, aunque, también, apunta que cabía tal posibilidad en interés de la protección de consumidor conforme al artículo 8 de la Directiva 93/13. Además, la Abogado General apuntó, consideramos que con acierto, que tal obligación de control en el ámbito del proceso monitorio mermaría la principal ventaja de este tipo de procesos: la rápida satisfacción de créditos pecuniarios no impugnados. Vid., en particular, los apartados 48 a 56 y 79.

${ }^{30}$ Apartado 54.
} 
midores de la protección que pretende garantizar la Directiva 93/13» $»^{31}$. En el mismo sentido, se volvió a pronunciar el TJUE en contra de la ley procesal española, antes de la reforma que permitió un control de oficio de esta cuestión previo a la expedición del requerimiento de pago, por no permitir que el juez que conoce de la ejecución del requerimiento de pago pudiera apreciar de oficio el carácter abusivo de una cláusula contenida en un contrato celebrado entre un profesional y consumidor cuando la autoridad que conoció de la petición inicial de monitorio carecía de competencia para realizar dicho control ${ }^{12}$.

19. A raíz de esta sentencia, se introdujo el nuevo art. 815.4 de la LEC que prevé, en caso de que el crédito se funde en un contrato entre un empresario o profesional y un consumidor o usuario, un control de oficio de la eventual abusividad de las cláusulas de dicho contrato previo a la emisión del requerimiento de pago. Así, el Letrado de la Administración de Justicia (LAJ), en este caso, antes de efectuar el requerimiento, «dará cuenta al juez para que pueda apreciar el posible carácter abusivo de cualquier cláusula que constituya el fundamento de la petición o que hubiese determinado la cantidad exigible». Si el juez «apreciare que alguna cláusula puede ser calificada como tal, dará audiencia por cinco días a las partes»; una vez oídas éstas, sin que para ello sea preceptivo abogado y procurador ${ }^{33}$, resolverá mediante auto dentro de los cinco días siguientes. El auto que estime el carácter abusivo de algunas de las cláusulas declarará la improcedencia del proceso o la continuación del procedimiento sin la aplicación de estas cláusulas. Si se declarase la inexistencia de cláusula abusiva alguna, el LAJ emitirá el requerimiento de pago. Este auto podrá ser recurrido mediante recurso de apelación.

20. Sin embargo, después de esta sentencia era de esperar que el problema se trasladara al proceso monitorio europeo ${ }^{34}$, ya que ninguna disposición de su reglamento prevé un control de tal tipo, más aún cuando éste es de carácter puro —o híbrido- y no documental. Y esto es lo que ha sucedido con la STJUE de 19 de diciembre de 2019, Bondora, asuntos acumulados C-453/18 y C-494/18, precisamente a raíz de cuestiones prejudiciales de origen español.

Esta sentencia adquiere particular relevancia, además, porque ha sido dictada en un contexto donde ha habido un incremento exponencial del recurso al proceso monitorio europeo (un 798,3\% en el año 2018). Aumento debido a una práctica que seguían los conocidos, vulgarmente, como "fondos buitres" para evitar el control que se ejerce sobre el principio de prueba documental exigido en nuestro proceso monitorio para acreditar la deuda reclamada ${ }^{35}$ y por el control de oficio realizado por parte del juez sobre la eventual existencia de cláusulas abusivas ${ }^{36}$. Aunque en origen se trataban de deudas puramente nacio-

\footnotetext{
${ }^{31}$ Apartado 55.

${ }^{32}$ STJUE de 18 de febrero de 2016, Finanmadrid, asunto C-49/14, apartado 55. En el mismo sentido, ATJUE de 21 de junio de 2016, Aktiv Kapital Portfolio AS, asunto C-122/14, apartado 39.

${ }^{33}$ Lo que, como apunta J. F. Herrero Perezagua en «Cinco preguntas sobre la transformación del monitorio», Revista General de Derecho Procesal, ${ }^{\circ}$ 45, 2018, p. 31, «se aviene mal con el carácter técnico-jurídico de una cuestión como la referida».

${ }^{34}$ Según un estudio que encargó la Comisión Europea a un consorcio de universidades europeas liderado por el Max Planck Institute Luxembourg, «An evaluation study of national procedural laws and practices in terms of their impact on the free circulation of judgments and on the equivalence and effectiveness of the procedural protection of consumers under EU consumer law», Strand 2, Procedural Protection of Consumers, JUST/2014/RCON/PR/CIVI/0082, http://ec.europa.eu/newsroom/just/document. cfm?action=display\&doc_id=49503, p. 231, en Alemania, Eslovenia, Estonia, Francia, Hungría, Polonia, Portugal y Suecia en sus procesos monitorios, cuando el demandado es un consumidor, no se realiza ningún tipo de control de oficio. Además, si cogemos como ejemplo Alemania -país sobre el que volveremos infra-, vemos que tampoco hay este control de oficio en la fase de ejecución del requerimiento de pago, solo habría tal examen si el consumidor se opusiera a la ejecución o hubiese formulado oposición al inicio del monitorio (vid. el national report - consumer protection strand de Alemania realizado por C. KERN y T. PFEIFFER). Es decir, en Alemania se estaría incumpliendo la jurisprudencia europea sobre el control de oficio de cláusulas abusivas en procesos de naturaleza monitoria; lo que es realmente preocupante, porque no puede ser que solo se aplique la interpretación del derecho de la Unión europea realizada por el TJUE en aquel país del órgano jurisdiccional que planteó la cuestión prejudicial.

${ }_{35}$ Aquí algunos casos en los que se inadmite la petición de monitorio porque se aportan documentos parciales o, tan solo, fotocopias: AAT de la Audiencia Provincial de Madrid de la Sec. 20. ${ }^{\text {a }}$, de 4 de febrero de 2013 y de 16 de noviembre de 2012; y de la Sec. 21. a, de 21 de noviembre de 2012.

${ }^{36}$ El ATJUE de 21 de junio de 2016, Aktiv Kapital Portfolia AS, asunto C-122/14, por ejemplo, es una muestra de los impedimentos que encontraban los fondos de capital de riesgo para cobrar los créditos a través del proceso monitorio español debido al control de oficio de eventuales cláusulas abusivas.
} 
nales, la cesión del crédito a fondos de capital de riesgo con sede en otro Estado miembro (normalmente, Luxemburgo, Estonia o Malta) permitía acudir al proceso monitorio europeo. ¿Y cuáles eran las ventajas del proceso monitorio europeo? Precisamente la inexistencia de dichos controles, ni documental ni sobre la eventual abusividad en el caso de contratos celebrados con consumidores, ni sobre la eventual abusividad en el caso de contratos celebrados con consumidores ${ }^{37}$.

21. En la Ley de Enjuiciamiento Civil, su disposición final vigésima tercera, relativa a las medidas adoptadas para facilitar la aplicación en España del RPME, establece, por una parte, que «la petición de requerimiento europeo de pago se presentará a través del formulario A que figura en el anexo I [del Reglamento n. ${ }^{\circ}$ 1896/2006], sin necesidad de aportar documentación alguna, que en su caso será inadmitida» y, por otra, que «las cuestiones procesales no previstas en el Reglamento (CE) n. ${ }^{\circ}$ 1896/2006 para la expedición de un requerimiento europeo de pago se regirán por lo previsto [en la LEC] para el proceso monitorio».

22. Los jueces españoles, en Banco Español de Crédito, consideraron que, al ser el crédito fundado en un contrato de préstamo celebrado entre un profesional y un consumidor, el requirente debía aportar la documentación acreditativa de la deuda, en concreto, el contrato de préstamo, para poder controlar el eventual carácter abusivo de alguna de sus cláusulas; aplicando así el control de oficio que se estableció en el monitorio nacional (815.4 LEC) por exigencia de la jurisprudencia europea. El requirente se negó a presentar tal documentación aduciendo que ni el RPME (arts. 8 y 12) — de ahí su naturaleza no documental — ni la mencionada disposición final vigésima tercera de la LEC le obligaban a aportar documento alguno.

23. La petición de requerimiento se presenta mediante el formulario A, que figura en el anexo I del RPME (art. 7.1), en dicha petición, entre otros elementos, deberá indicarse el petitum — «el importe de la deuda, incluido el principal y, en su caso, los intereses, las penalizaciones contractuales y las costas» (art. 7.2.b)—, la causa de pedir — «incluida una descripción de las circunstancias invocadas como fundamento de la deuda y, en su caso, de los intereses reclamados» (art. 7.2.d) - y una descripción de los medios de prueba que acrediten la deuda (art.7.2.e). El órgano jurisdiccional examinará, lo antes posible y basándose en el formulario de la petición, si se cumplen los requisitos establecidos y si la petición resulta fundada, pudiendo este examen operar como un procedimiento automatizado (art. 8).

24. El RPME no exige aportación de medio de prueba alguno que acredite la deuda, sino tan solo su descripción ${ }^{38}$, por lo que el órgano jurisdiccional, para poder examinar de oficio la eventual abusividad de las cláusulas contractuales, debería pedir al acreedor que aporte información complementaria, es decir, documentos, convirtiéndose, así, el proceso, de facto, en documental.

25. Es cierto que el artículo 9 del RPME dispone que el órgano jurisdiccional, a través del formulario b (anexo II), puede solicitar que el acreedor complete o rectifique la petición, pero circunscribiendo esta solicitud a un incumplimiento de los requisitos establecidos en el artículo 7. Por lo que consideramos que, al menos de lege lata, no podría solicitarse una copia del contrato, ya que su aportación no es requisito para formular correctamente una petición de requerimiento europeo de pago. Nuestra tesis, además, sería conforme con la STJUE de 13 de diciembre de 2012, Iwona Szyrocka c. SiGer Te-

${ }^{37}$ En relación con esta cuestión, debo referirme al Prof. YBARRA Bores, el cual me ilustró sobre estas prácticas. También se hace eco de esta praxis la Memoria sobre el estado, funcionamiento y actividades del Consejo General del Poder Judicial y de los juzgados y tribunales en el año 2018, pp. 355 y 356.

${ }^{38}$ En el apartado 10 del formulario A el acreedor puede apuntar los medios de prueba de los que dispone y su descripción, incluidas las pruebas documentales; sin embargo, por descripción parece que se refiere únicamente a su identificación, ya que el espacio que deja el formulario para la descripción de las pruebas es minúsculo y en las indicaciones para cumplimentar el formulario de petición se señala que «en la casilla [Descripción de las pruebas] figurará, por ejemplo, el título, denominación o número de referencia del documento en cuestión, la cuantía mencionada en el mismo, o el nombre del testigo o del perito»; es decir, descripción más bien poca. No obstante, el campo 11 del formulario permite aportar información complementaria o, también, emplearse en caso de necesitar más espacio para cualquier campo anterior. 
chnologie GmbH, asunto C-215/11, que declaró que el «artículo 7 del Reglamento nº 1896/2006 regula de manera exhaustiva los requisitos que debe cumplir la petición de requerimiento europeo de pago ${ }^{39}$.

26. No obstante, el TJUE declara que, en virtud de los arts. 7 y 9, el órgano jurisdiccional que conoce del proceso monitorio «puede pedir al acreedor información complementaria relativa a las cláusulas que este invoca para acreditar la deuda, como la reproducción de todo el contrato o la presentación de una copia de este, con el fin de poder examinar el carácter eventualmente abusivo de tales cláusulas» ${ }^{40}$. El TJUE dice que el que se «requiera al demandante que aporte el contenido del documento o de los documentos en los que basa su petición se integra simplemente en la materia probatoria del proceso, ya que ese requerimiento tiene por único objeto determinar si la petición es fundada $\rangle^{41}$. De este modo, dando respuesta a varias cuestiones prejudiciales planteadas, concluyó que «el artículo 7, apartado 2, letras d) y e), del Reglamento n. ${ }^{\circ}$ 1896/2006 y los artículos 6, apartado 1, y 7, apartado 1, de la Directiva 93/13, tal como han sido interpretados por el Tribunal de Justicia y a la luz del artículo 38 de la Carta, deben interpretarse en el sentido de que permiten que un "órgano jurisdiccional", según la definición de dicho Reglamento, que conoce de un proceso monitorio europeo pida al acreedor información complementaria relativa a las cláusulas contractuales que este invoca para acreditar la deuda de que se trate, con el fin de controlar de oficio el carácter eventualmente abusivo de esas cláusulas, y de que, en consecuencia, se oponen a una normativa nacional que declara inadmisible la documentación complementaria aportada a tal efecto ${ }^{42}$.

Enlazando otra vez con las modificaciones que ha sufrido el proceso monitorio español a raíz de la jurisprudencia europea en materia de cláusulas abusivas, queremos señalar que lo que más desnaturaliza el proceso monitorio no es ya el control de oficio del órgano jurisdiccional de la eventual concurrencia de cláusulas abusivas, sino que se introduzca un trámite de audiencia en el que se llama no solo al acreedor, sino, también, al deudor. Una de las características fundamentales de un proceso monitorio es que la contradicción se pospone a una eventual oposición del deudor al requerimiento de pago, a partir de la cual se traslada el litigio al procedimiento declarativo ordinario que corresponda donde la contradicción queda garantiza. Se apuntó que el requisito de audiencia era ineludible por exigencia de la propia jurisprudencia europea: «el principio de contradicción obliga, con carácter general, al juez nacional que haya comprobado de oficio el carácter abusivo de una cláusula contractual a informar de ello a las partes procesales y ofrecerles la posibilidad de debatir de forma contradictoria según las normas previstas al respecto por las reglas procesales nacionales» (STJUE de 21 de febrero de 2013, Banif Plus Bank, asunto C-472/11, apartado 36$)^{43}$. Sin pretender ahondar en el prolijo debate que ha suscitado en la doctrina española esta cuestión ${ }^{44}$, tan solo quiero realizar algunas consideraciones. En el caso Banco Español de Crédito en ningún momento se hace referencia, como señala GASCÓN InCHAUSTI, a que sea preceptiva la celebración

\footnotetext{
${ }^{39}$ Apartado 32.
}

${ }^{40}$ Apartado 50.

${ }^{41}$ Apartado 52.

42 Apartado 54.

${ }^{43}$ L. Gómez Amigo, en «Control de las cláusulas abusivas y garantías procesales en los procesos con técnica monitoria, a la luz de la jurisprudencia reciente», Revista General de Derecho Procesal, $\mathrm{n}^{\circ}$ 49, 2019, p. 6, y en «La evolución del proceso monitorio. En particular, su reforma por la Ley 42/2015, de 5 de octubre», Práctica de Tribunales. Revista especializada en Derecho Procesal Civil y Mercantil, núm. 126, mayo-junio 2017, epígrafe 4.2.

vid., también, el apartado 35 de la misma sentencia: «Esta posibilidad ofrecida al consumidor de expresar su opinión sobre este extremo obedece también a la obligación que incumbe al juez nacional, como se ha recordado en el apartado 25 de la presente sentencia, de tener en cuenta, en su caso, la voluntad manifestada por el consumidor cuando, consciente del carácter no vinculante de una cláusula abusiva, manifiesta, no obstante, que es contrario a que se excluya, otorgando así un consentimiento libre e informado a dicha cláusula».

${ }^{44}$ Vid., entre otros, J. BANACloche PALAO, «Algunas reflexiones sobre el Anteproyecto de reforma parcial de la Ley de Enjuiciamiento Civil en materia de procuradores, juicio verbal y monitorio», Diario La Ley, nº 8137, 30 de julio de 2013; B. SÁnCHEZ LÓPEZ, «Recorrido por las sucesivas reformas del procedimiento monitorio y el reto del control de oficio de las cláusulas abusivas en contratos de consumo», en I. Díez-Picazo Giménez, y J. Vegas Torres, (coords.), Derecho, Justicia, Universidad. Liber amicorum de Andrés de la Oliva Santos, vol. II, Madrid, Ed. Ramón Areces, 2016, pp. 2833 a 2839; L. GómEz AMIGo, «Control de las cláusulas abusivas y garantías procesales en los procesos con técnica monitoria, a la luz de la jurisprudencia reciente», op. cit., p. 6, y en «La evolución del proceso monitorio. En particular, su reforma por la Ley 42/2015, de 5 de octubre», op. cit., epígrafe 4.2.; y J. F. Herrero Perezagua, «Cinco preguntas sobre la transformación del monitorio», op. cit., pp. 29 a 35. 
de una audiencia con todas las partes, sino que en el ámbito del proceso monitorio critica que el juez «aun cuando disponga de los elementos de hecho y de Derecho necesarios al efecto» no pueda examinar de oficio el eventual carácter abusivo de una cláusula ${ }^{45}$. A esto queremos añadir tres cuestiones. La primera: la jurisprudencia a la que se recurre para declarar que el control de oficio de cláusulas abusivas en el proceso monitorio debe ir acompañado de un incidente contradictorio no se refiere a procesos de técnica monitoria y hace referencia a tal obligación utilizando términos como «con carácter general $»^{46} \mathrm{o}$ «por regla general» ${ }^{47}$; es decir, que puede haber excepción y ésta podría ser el monitorio. La segunda es que el carácter prescindible de tal vista en el ámbito de un proceso monitorio creemos que se avala por la STJUE de 19 de diciembre de 2019, Bondora, asuntos acumulados C-453/18 y C-494/18, ya que ésta solo declara que el proceso monitorio europeo permite que el tribunal que conozca del asunto solicite «al acreedor información complementaria relativa a las cláusulas contractuales que este invoca para acreditar la deuda de que se trate, con el fin de controlar de oficio el carácter eventualmente abusivo de esas cláusulas» sin que en ningún momento aluda a la necesidad de abrir un incidente contradictorio con ambas partes - lo que tampoco prevé, ni mucho menos, el propio RPME-. Y la tercera es que el análisis de la abusividad en el seno del proceso monitorio no equivale al enjuiciamiento propio de un proceso plenario de cognición; el juez realiza, de oficio, una función de mera prevención para garantizar la efectividad de la protección del consumidor exigida por el Derecho europeo ${ }^{48}$, por lo que su decisión en este estadio no tendrá eficacia de cosa juzgada material ${ }^{49}$, lo que refuerza, según nuestro parecer, el carácter innecesario de una vista contradictoria.

27. En el fondo, con esta resolución estamos pasando por el tamiz del TJUE y de la Directiva 93/13 - y del artículo 38 de la CDFUE - no una disposición nacional, sino una propiamente europea, el RPME; aunque se diga que la disposición final 23 $3^{\mathrm{a}} .2 \mathrm{LEC}$ es contraria al Derecho europeo por declarar inadmisible la documentación complementaria. Por ello, queremos manifestar que la disposición final vigésima tercera de la LEC es totalmente escrupulosa con el RPME, el art. 7.1 requiere que la petición de requerimiento europeo de pago se presente a través del formulario $\mathrm{A}$, sin acompañamiento de documentación alguna, cosa distinta es que luego el art. 9 RPME permita la posibilidad de completar o rectificar la petición si no se cumplen los requisitos establecidos en el artículo 7, cosa que obviamente no prohíbe la disposición española. Entendemos el proceder del TJUE y de que este intente forzar al máximo el texto del RPME para dar encaje a la jurisprudencia europea en materia de protección de derecho de consumidores; sin embargo, tal vez, lo honesto -aunque más problemático y, tal vez, inviable- sería haber respondido

${ }^{45}$ F. Gascón InChausti, Derecho europeo y legislación procesal civil nacional: entre autonomía y armonización, op. cit., p. 130.

${ }^{46}$ SSTJUE de 21 de febrero de 2013, Banif Plus Bank, asunto C-472/11, apartados 30 y 36, y de 30 de mayo de 2013, Dirk Frederik Asbeek Brusee, asunto C-488/11, apartado 52.

${ }^{47}$ STJUE de 21 de febrero de 2013, Banif Plus Bank, asunto C-472/11, apartado 31.

${ }^{48}$ La Abogado General, en las conclusiones presentadas en Bondora, realiza las siguientes matizaciones: «...el control ejercido por el juez se limita estrictamente a la comprobación del carácter potencialmente abusivo, a primera vista, de las cláusulas invocadas (al examinar la apariencia de buen derecho de la petición)» (apartado 131); «Esta solución garantiza una protección efectiva del consumidor, ya que posibilita que el juez deniegue la expedición de un requerimiento de pago (o que expida un requerimiento de pago parcial) cuando las cláusulas invocadas parezcan, a primera vista, potencialmente abusivas» (apartado 133); «En efecto, el juez ante el que se presenta la petición no se pronuncia sobre el fondo y no anula las cláusulas contractuales controvertidas. Simplemente se niega a expedir un título ejecutivo en virtud del Reglamento n. ${ }^{\circ}$ 1896/2006, basándose en una apariencia de derecho, sin perjuicio de los derechos del acreedor, que habrán de ser objeto de un debate contradictorio ante el órgano jurisdiccional que conozca del fondo» (nota 74); «...cabe señalar también que, con arreglo a los artículos 8 y 11 del Reglamento n. ${ }^{\circ}$ 1896/2006, el juez ante el que se haya presentado la petición de requerimiento de pago solo está llamado a pronunciarse sobre la apariencia de buen derecho de la petición al estimarla o desestimarla» (apartado 137); «...una eventual desestimación de la petición (debido, por ejemplo, a la existencia de dudas sobre el carácter potencialmente abusivo de las cláusulas invocadas) obviamente no impedirá al acreedor cobrar su crédito, en su caso, por otras vías procesales» (apartado 138).

$49 \mathrm{Vid}$. B. SÁNChez López, «Recorrido por las sucesivas reformas del procedimiento monitorio y el reto del control de oficio de las cláusulas abusivas en contratos de consumo», op. cit., pp. 2836 y 2837. Así, «en consecuencia, ya sea por falta de cosa juzgada material del auto, ya sea por falta de identidad de res, el control a limine litis del juez en este momento del procedimiento monitorio no puede impedir ni que el acreedor acuda a un proceso declarativo plenario en defensa de la validez de cláusulas cuestionadas de oficio por el juez en este incidente..., ni que el consumidor deudor pueda formular oposición en el seno del procedimiento monitorio para que la eventual nulidad de las cláusulas en cuestión se diriman en el proceso plenario correspondiente». 
la cuestión prejudicial cuarta del asunto C-494/18 permite el control de oficio de la existencia de cláusulas abusivas con carácter previo a expedir el requerimiento europeo de pago, por lo que no sería válido por ser contrario al art. 38 CDFUE y al art. 6.1 TUE.

\section{Algunas propuestas de modificación del RPME (para facilitar la extensión de su ámbito de apli- cación)}

28. En este trabajo no pretendemos plantear una refundición total del RPME, sino tan solo los retoques que consideramos más necesarios. Aunque, obviamente, facilitaría la extensión del ámbito de aplicación del proceso monitorio europeo a los litigios internos un instrumento lo más perfeccionado posible, hemos usado el paréntesis en el título de este epígrafe porque creemos que estas propuestas pueden ser igualmente útiles para una mejora del proceso monitorio europeo que no llevara aparejada una modificación de su ámbito de aplicación ${ }^{51}$.

\section{1. ¿Nos conviene un proceso monitorio europeo documental?}

29. El proceso monitorio europeo se diseñó partiendo de los diversos procesos monitorios existentes en la Unión Europea ${ }^{52}$, por lo que el resultado fue un proceso que contenía características de los dos principales modelos de procesos monitorios existentes en Europa: el puro y el documental ${ }^{53}$. El PME es más próximo al puro porque ha apostado por su principal rasgo: la emisión del requerimiento de pago no necesita ningún principio de prueba documental de los hechos constitutivos del crédito, sino que es suficiente la mera afirmación del acreedor. De ahí que el RPME exija que el demandante declare «que la información suministrada es, a su leal saber y entender, verdadera y [reconozca] que cualquier declaración falsa deliberada podría acarrearle las sanciones oportunas con arreglo al Derecho del Estado miembro de origen» (art. 7.3) y, a su vez, se informe al demandado de que «el requerimiento fue expedido únicamente sobre la base de la información facilitada por el demandante, sin que la misma haya sido comprobada por el órgano jurisdiccional» (art. 12.4.a $)^{54}$. Sin embargo, este último inciso al que nos hemos referido chirria con el proceso monitorio puro por el que parece, ab initio, que se opta, ya que, acto seguido, se exige por parte del órgano jurisdiccional un examen del fundamento de la petición inicial de PME — control más propio de los monitorios documentales- (art. 8$)^{55}$. Examen que no encaja bien, tampoco, en un proceso monitorio puro porque así no sería factible, en principio, la tramitación automática a través de medios informáticos en la que el juez no interviene directamente, sino que delega en otros miembros de la oficina judicial; por ello, el legislador europeo trató de salvar tal óbice con el siguiente inciso final del art. 8: «este examen podrá revestir la forma de un procedimiento automatizado» ${ }^{56}$. Otra característica más propia de los procesos monitorios documentales que adopta el monitorio europeo es constituirse como un procedi-

${ }^{50}$ Dicha cuestión prejudicial reza así: «4) En el supuesto de que no sea posible controlar de oficio, en la redacción actual del Reglamento n. ${ }^{\circ}$ 1896/2006, la existencia de cláusulas abusivas con carácter previo a expedir el requerimiento europeo de pago, se pregunta al TJUE para que se pronuncie sobre la validez del citado Reglamento, por si es contrario al artículo 38 [de la Carta] y [al] artículo 6.1 [TUE]».

${ }^{51} \mathrm{Y}$, es más, algunas reflexiones pueden servir, también, para repensar algunas cuestiones del proceso monitorio nacional.

${ }^{52}$ Libro Verde sobre el proceso monitorio europeo y las medidas para simplificar y acelerar los litigios d escasa cuantía, COM (2002) 764 final, epígrafe 3.

${ }_{3}$ Vid., sobre los principales modelos de técnica monitoria, P. CAlamandrei, El procedimiento monitorio (trad.: S. Sentís Melendo), Editorial Bibliográfica Argentina, Buenos Aires, 1946, y J. P. Correa Delcasso, El proceso monitorio, Ed. Bosch, Barcelona, 1998. En extensión, vid. sobre la naturaleza y los rasgos fundamentales del proceso monitorio europeo a L. GómEZ Amigo, El Proceso Monitorio Europeo, Aranzadi, Navarra, 2008, pp. 41 a 58, y a S. GARCía CANo, Estudios sobre el proceso monitorio europeo, Aranzadi, Navarra, 2008, pp. 56 a 63.

${ }^{54}$ Disposición similar a la del $\S 692$ I núm. 2 ZPO.

55 J. P. Correa Delcasso, El proceso monitorio europeo, Marcial Pons, Madrid, 2008, pp. 48 y 49.

${ }^{56}$ Tratamiento automatizado propio de los países en los que sus procesos monitorios pueden clasificarse como puros. Vid., por ejemplo, el § 689 I ZPO. Cfr. Libro Verde sobre el proceso monitorio europeo..., op. cit., epígrafe 3.3.4.4; L. GóMEZ AMIGO, El Proceso Monitorio Europeo, op. cit., pp. 44 y 45; J.P. Correa DelCasso, El proceso monitorio europeo, op. cit., p. 50. 
miento de una única fase, ya que los puros, como el alemán, suelen ser procedimientos compuestos por dos fases en las que hay, por lo tanto, dos posibilidades de oposición ${ }^{57}$.

30. Sin embargo, la exigencia de un examen de oficio de la eventual abusividad de las cláusulas en las que se funda el crédito reclamado dificulta la aplicación de las propias disposiciones del RPME. Veámoslo.

31. En primer lugar, enlazando con lo apuntado supra con respecto al control de oficio de las clausulas abusivas, creemos que una jurisprudencia que, forzando al máximo los arts. 7.1 y 9.1, declare que el órgano judicial debe tener la posibilidad de solicitar al acreedor información complementaria sobre las cláusulas que afectan al crédito - en definitiva, solicitar una copia del contrato - no es la más adecuada. Tampoco lo es, creemos, una simple modificación del inciso final de la Disposición final $23^{\circ} .1$ LEC, sino que lo adecuado sería una reforma del RPME que introdujera una disposición similar a la del art. 815.4 LEC. El problema es que, al estar ante un proceso no documental, el juez que conoce del proceso monitorio, si considera que está ante un contrato entre una empresa o profesional y un consumidor o usuario, deberá solicitar al acreedor la documentación pertinente para poder valorar el carácter abusivo de cualquier cláusula que fundamente la petición o determine la cantidad exigible, lo que afectará, inevitablemente, a las cualidades intrínsecas de un proceso monitorio: la eficacia y agilidad. Por lo tanto, para salvaguardar algo de dicha agilidad podría ser mejor que la documentación debiera aportarse junto con la petición inicial de PME.

Como apuntamos supra, este control de oficio no tendría por qué ir acompañado de una vista. Una propuesta que podría servir de orientación para configurar tal control es la que realizó BANACLOCHE PALAO antes de la instauración del nuevo art. 815.4 $\mathrm{LEC}^{58}$. Este autor proponía postergar el control al final de la tramitación del monitorio, antes de la formación del título ejecutivo. Si el deudor pagase, no sería necesario control judicial alguno, ya que el supuesto equivaldría a aquél en el que se paga sin instarse actuación judicial alguna; si hubiera oposición, el análisis de la eventual abusividad se ventilaría en el proceso ordinario que correspondiese; y si no hubiera comparecido —es decir, ni hubiera pagado ni formulado oposición—, entonces, se controlaría el eventual carácter abusivo de las cláusulas antes de emitir el título ejecutivo.

32. El control que impone la jurisprudencia europea en materia de consumidores se adapta mejor a un monitorio de carácter documental ${ }^{59}$. Una opción sería convertir el PME en documental solo para los supuestos en los que la deuda reclamada se funde en un contrato celebrado entre un profesional y un consumidor, de forma que en la petición inicial de requerimiento europeo de pago debiera aportarse copia del contrato. El problema es que, aunque el concepto de consumidor y profesional esté bien delimitado por la jurisprudencia ${ }^{60}$, habrá demandantes que no presenten documento alguno porque consideren que la contraparte de la relación contractual que funda la deuda no era un consumidor o que el contrato fue celebrado independientemente de cualquier actividad o finalidad profesional.

33. Además, como apuntamos supra, un tratamiento informatizado de las peticiones de proceso monitorio o en los supuestos en los que se delega su tratamiento en miembros de la oficina judicial que no tienen potestad jurisdiccional dificulta un control de oficio de las eventuales cláusulas abusivas, ya que está claro que tal examen — juicio — debe realizarlo el titular de la potestad jurisdiccional ${ }^{61}$.

\footnotetext{
57 Infra, en lo referido a la notificación, se comenta esta estructura del proceso monitorio alemán.

58 J. Banacloche Palao, «Algunas reflexiones sobre el Anteproyecto de reforma parcial de la Ley de Enjuiciamiento Civil en materia de procuradores, juicio verbal y monitorio», op. cit.

59 Así lo reconoce lo propia Abogado General (Conclusiones de la Abogado General presentadas el 31 de octubre de 2019 , Bondora, asuntos acumulados C-453/18 y C-494/18, apartado 84).

$60 \mathrm{Vid}$. algunas sentencias recientes que recogen la jurisprudencia consolidada al respecto: SSTJUE de 14 de febrero de 2019, asunto C-630/17, Anica Milivojevic c. Raiffeisenbank St. Stefan-Jagerberg-Wolfsberg eGen) y de 25 de enero de 2018 , asunto C-498/16, Schrems.

${ }^{61}$ Así, en la STJUE de 14 de junio de 2012, Banco Español de Crédito, asunto C-618/10, se deja claro que, en el marco de un proceso monitorio, el examen del eventual carácter abusivo de una cláusula recae sobre el juez. Véase, también, en el
} 
34. Por todas estas cuestiones, creemos que debería valorarse la transformación del proceso monitorio europeo en documental. ¿Realmente sería un cambio traumático? En el proceso monitorio español, por ejemplo, el principio de prueba documental que se requiere para admitir la petición inicial no es, para nada, restrictivo: «[m]ediante documentos, cualquiera que sea su forma y clase o el soporte físico en que se encuentren, que aparezcan firmados por el deudor o con su sello, impronta o marca o con cualquier otra señal, física o electrónica»o «facturas, albaranes de entrega, certificaciones, telegramas, telefax o cualesquiera otros documentos que, aun unilateralmente creados por el acreedor, sean de los que habitualmente documentan los créditos y deudas en relaciones de la clase que aparezca existente entre acreedor y

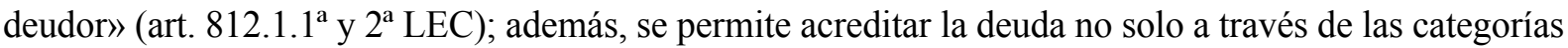
documentales citadas, sino, también, «[c]uando, junto al documento en que conste la deuda, se aporten documentos comerciales que acrediten una relación anterior duradera» $\mathrm{y}$ «[c]uando la deuda se acredite mediante certificaciones de impago de cantidades debidas en concepto de gastos comunes de Comunidades de propietarios de inmuebles urbanos». Es decir, tenemos la impresión de que hay pocos créditos que no tengan ningún tipo de soporte documental que pueda incluirse en alguna de estas categorías.

\section{Reconsideración de la notificación del requerimiento europeo de pago}

\section{A) La notificación del requerimiento europeo de pago. Statu quo}

35. En el ámbito de un proceso monitorio, la ya de por sí importante primera notificación al demandado adquiere aún más relevancia. Una vez el acreedor ha presentado la petición de proceso monitorio y el tribunal declara la misma admisible, se notifica el requerimiento de pago al deudor. Notificado tal requerimiento, todo depende de la conducta del deudor: puede pagar; formular oposición, lo que implicará que el litigio se enjuicie a través del proceso ordinario que corresponda; o, si no comparece, tal requerimiento adquirirá directamente fuerza ejecutiva. De ahí que la notificación del requerimiento de pago para que el demandado tenga conocimiento del proceso, y con tiempo suficiente, para que tenga la posibilidad de formular oposición - en definitiva, ejercer su derecho de defensa - sea vital. Por ello, con carácter general, los procesos que recurren a la técnica monitoria no permiten métodos de notificación ficticios.

36. Al proceso monitorio europeo, además de los riesgos inherentes a la naturaleza transfronteriza del proceso, se le suma la supresión del exequatur y la imposibilidad de impugnar su reconocimiento y ejecución en el Estado de ejecución. Por estos motivos, aunque se estableció que el requerimiento europeo de pago se ha de notificar al demandado de conformidad con el Derecho nacional que corresponda (lex fori), la forma de notificación debe respetar unas normas mínimas (art. 12.5), las cuales son idénticas a las previstas en el Reglamento (CE) n ${ }^{\circ}$ 805/2004 del Parlamento Europeo y del Consejo, de 21 de abril de 2004, por el que se establece un título ejecutivo europeo para créditos no impugnados $(\mathrm{RTEE})^{62}$. Estas normas mínimas permiten renunciar a un proceso intermedio en el Estado miembro de ejecución para que la resolución en cuestión sea reconocida y ejecutable en dicho Estado miembro ${ }^{63}$ porque el control de las garantías se adelanta al proceso declarativo y se traslada al estado de origen.

37. La adopción de unas normas mínimas implica que los Estados miembros no se vean obligados, al menos directamente, a la adaptación de sus normas internas en materia de notificación; sin embargo, si un Estado no tuviera ningún modo de notificación que cumpliese con los requisitos mínimos previstos por

mismo sentido, STJUE de 18 de febrero de 2016, Finanmadrid, asunto C-49/14. Asimismo, por ejemplo, vid. la STJUE de 16 de febrero de 2017, asunto C-503/15, aunque tan solo sea a efectos de la facultad para plantear una cuestión prejudicial (art. 267 TFUE), en la que no considera órgano jurisdiccional al secretario judicial; sin embargo, al mismo tiempo, deja caer que en el procedimiento de jura de cuentas el control de las cláusulas abusivas no le corresponderá al LAJ, sino al Juez de ejecución que corresponda (apartado 42).

${ }^{62}$ La única diferencia es que en el art. 13 relativo a la notificación con acuse de recibo no se prevé el apartado segundo del art. 13 del TEE relativo a la vista, lo que es normal debido a la propia estructura del proceso monitorio europeo.

${ }^{63}$ Artículo 1.b. 
este Reglamento, el proceso monitorio europeo «no estaría vigente, de facto, en tal Estado» ${ }^{64}$. El Estado no necesita recoger de manera exhaustiva todos los modos de notificación previstos en los artículos $13 \mathrm{y}$ 14 RPME, sino que es suficiente que la notificación del requerimiento de pago de acuerdo con el Derecho nacional del Estado en el que deba practicarse se adapte a uno de los modos previstos en el art. 13 o 14. Por ejemplo, en España, los modos previstos en el art. 13 encajan con nuestra LEC; sin embargo, los del art. 14 no todos. En España el requerimiento europeo de pago podría notificarse de acuerdo con los artícu$\operatorname{los} 160,161$ y $162^{65}$, es decir, remisión de las comunicaciones por correo con acuse de recibo por parte del destinatario, modo que sería compatible con el art. 13.c); comunicación por entrega personal, compatible con los arts. 13.a) y b) y 14.1 a) y b ${ }^{66}$; y comunicación por medios electrónicos, informáticos y similares, compatible con el art. 13.d). El depósito del requerimiento en el buzón del demandado [14.1.c)] no es un modo previsto en nuestro ordenamiento jurídico. El art. 14.1.d) permite la notificación del requerimiento a través del depósito en una oficina de correos o ante las autoridades públicas competentes junto con la notificación escrita de dicho depósito en el buzón del demandado, si en ésta consta claramente el carácter judicial del escrito o el hecho de que tiene como efecto jurídico hacer efectiva la notificación y, por tanto, constituir la fecha de inicio del cómputo de los plazos pertinentes; sin embargo, aunque esta forma de notificación no encuentra acomodo en nuestra LEC, también es cierto que está bastante extendido en la práctica que si al practicarse la notificación por remisión por correo postal no se encuentra a nadie en el domicilio del destinatario se deje un aviso para que el destinatario acuda a recoger la comunicación en la oficina de correos que corresponda ${ }^{67}$. El art. 14.1.e prevé la notificación por correo sin acuse de recibo cuando el demandado esté domiciliado en el Estado miembro de origen, siempre y cuando la persona competente que efectúe la notificación practique diligencia en la que conste la forma utilizada, la fecha y en el caso de que el requerimiento se hubiera notificado a un receptor subsidiario, el nombre de dicha persona y su relación con el demandado (14.3); a priori, esta forma de notificación no cabe en nuestro ordenamiento jurídico, pero si hubiera acuse de recibo por parte del receptor subsidiario, hay que apuntar que, aunque el art. 160 LEC (referido a la remisión por correo) nada dice al respecto, los tribunales validan la notificación vía correo postal a los mismos receptores subsidiarios a los que se refiere el art. 161.3 LEC en el ámbito de la comunicación personal ${ }^{68}$. Por último, la comunicación por medios electrónicos con acuse de recibo acreditado mediante una confirmación automática de entrega, siempre que el demandado haya aceptado expresamente con anterioridad este medio de notificación, no casa con el requisito de constancia de la efectiva recepción impuesto para el primer emplazamiento (arts. 155.4 y 158 LEC) y para la comunicación a través de medios electrónicos (art. 162.1) ${ }^{69}$.

38. El propio RPME, en su considerando 20, declara que los métodos de notificación que prevé ofrecen «bien una certidumbre total (artículo 13) o bien un alto grado de probabilidad (artículo 14) de que el documento notificado ha sido recibido por su destinatario». Sin embargo, afirmar que todos los modos del art. 14 tienen un alto grado de probabilidad de efectividad es, más bien, aventurado. En los supuestos a) y b) del art. 14, es decir, de entrega a un receptor subsidiario, puede augurarse, con alta probabilidad, que el

\footnotetext{
${ }^{64}$ Vid. L. Gómez Amigo, El proceso..., op. cit., p. 108 y nota 221 de la misma página.

${ }^{65}$ En el monitorio nacional, sin embargo, como veremos infra, solo por entrega personal de acuerdo con lo dispuesto en el art. 161 LEC (art. 815 LEC).

${ }^{66}$ Excepto que en España se permite la entrega personal en el centro de trabajo no ocasional que no sea establecimiento comercial, cuando en el RPME se limita al establecimiento comercial; y con referencia a los posibles receptores subsidiarios, en España se permite la entrega, a diferencia del RPME, no solo a los empleados del destinatario, sino que, en el lugar de trabajo no ocasional, se podrá a efectuar a cualquier persona que manifieste conocer el destinatario. Vid. F. GASCón InCHAUSTI, Título Ejecutivo Europeo para Créditos No Impugnados, Aranzadi, Navarra, 2005, pp. 129 y 130.

${ }^{67}$ Señalar que, de esta forma, solo puede recoger la comunicación el destinatario, no ningún receptor subsidiario.

${ }^{68}$ I. J. Cubillo López, La comunicación procesal en la nueva Ley de enjuiciamiento civil, Edersa, Madrid, 2001, pp. 182.

${ }^{69}$ A lo que hay que sumar que, ante las diversas interpretaciones que ofrece la LEC con respecto al primer emplazamiento a través de medios electrónicos, la jurisprudencia del TC ha vetado la utilización de dichos medios para la práctica de la primera comunicación al demandado no personado en el procedimiento (SSTC 6/2019, de 17 de enero, y 47/2019, de 8 de abril de 2019). Vid. J. I. Cerdé Messeguer, «La notificación electrónica de la demanda a las personas jurídicas: ¿Innovación tecnología o indefensión?», en Diario La Ley, n. ${ }^{\circ}$ 9388, 2 de abril de 2019, y I. J. CuBILlo LóPEZ, Actos procesales, comunicación procesal y medios electrónicos, La Ley Wolters Kluwer, 2019, Madrid, pp. 148 a 150.
} 
requerimiento llegue a manos del destinatario ${ }^{70}$; en una notificación con acuse de recibo acreditado mediante una confirmación automática de entrega, aunque sea sin acuse de recibo, al exigirse que el demandado haya aceptado expresamente con anterioridad tal medio de notificación, puede presumirse, también, un alto grado de probabilidad de eficacia (art. 14.1.f); en cambio, creemos que el grado de probabilidad de éxito decrece exponencialmente cuando en el buzón se deja un aviso del depósito del requerimiento en una oficina de correos o ante las autoridades públicas que correspondan (art. 14.1.d) ${ }^{71} \mathrm{o}$, muy especialmente, cuando la notificación consiste en el mero depósito del requerimiento en el buzón del demandado (art. 14.1.c) o - lo que en algunos casos viene a ser lo mismo - en el supuesto de notificación por correo sin acuse de recibo (art. 14.1.e). Además, el RPME deja patente en sus considerandos ${ }^{72}$ que no admite ningún tipo de notificación ficticia (como, por ejemplo, sería una notificación edictal). Sin embargo, considerar practicada la notificación — desplegando todos sus efectos — desde el momento en que ésta —o un aviso de la misma - se deposita en el buzón del demandado no es más que una presunción —y, por lo tanto, ficción — de que el demandado tiene conocimiento, y con tiempo suficiente, de ésta para poder defenderse. Es cierto, también, que todo lo que no sea una entrega con acuse de recibo del propio demandado implica una presunción, pero la probabilidad de certeza de tal presunción diferirá muchísimo si se le entrega la comunicación a un receptor subsidiario que conviva con el destinatario o si, simplemente, se deja un sobre en el buzón.

39. El art. 14.2, relativo a la notificación sin acuse de recibo, remarca que no puede practicarse la notificación si no se conoce con certeza el domicilio del demandado. Con carácter general —es decir, no refiriéndonos a las especialidades de la notificación de un requerimiento de pago-, en España, si suponemos que conocemos con certeza el domicilio del demandado y la comunicación por correo con acuse de recibo o por entrega personal del funcionario o procurador ha resultado infructuosa por no hallar a nadie en el domicilio, después de realizar las correspondientes averiguaciones sobre si realmente vive allí —y si éstas resultan, también, fallidas—, la notificación se practicará a través de edictos. En cambio, en otros países como Alemania o Italia, si se conoce tal domicilio, pero no es posible realizar la entrega de forma personal o a un receptor subsidiario de manera que se obtenga un acuse de recibo, se deja en el buzón la notificación o un aviso para que la recoja ${ }^{73}$. ¿Y qué implica tal diferencia? Pues que, ante el mismo supuesto, en Italia o Alemania podríamos expedir el requerimiento europeo de pago y en España no.

40. La Comisión Europea, en su informe sobre la aplicación del RPME, incentiva a usar la notificación mediante correo con acuse de recibo, por ser una de las vías de notificación de menor coste ${ }^{74}$.

\footnotetext{
${ }^{70}$ Notificación personal, en el domicilio del demandado, a personas que vivan en la misma dirección que éste o que estén empleadas en ese lugar (art. 14.1.a); o en el caso de un demandado que sea trabajador por cuenta propia, o de una persona jurídica, notificación personal en el establecimiento comercial del demandado a personas empleadas por él (art. 14.1.b).

${ }^{71}$ En el aviso que se deja en el buzón debe constar el carácter judicial del documento a notificar y que desde que se deposita tal aviso en el buzón la notificación se considera efectuada —iniciándose, así, desde ese momento el transcurso de los plazos pertinentes-.

${ }^{72}$ Vid. considerando 19.

${ }^{73}$ En Italia, en el caso de que se conozca el domicilio del demandado, pero haya sido imposible practicar la notificación por no encontrar al destinatario ni a ningún posible receptor subsidiario o éste último hubiera rechazado recibir la notificación, el ufficiale giudiziario deposita en el ayuntamiento del domicilio —o el funcionario de correos en la oficina correos si es vía postal — donde debe practicarse la notificación, pegándose, a su vez, un aviso en la puerta del domicilio o empresa u oficina del destinatario, informándole, además, de la situación por carta certificada con acuse de recibo (art. 140 c.p.c). La Corte Costituzionale, en su sentencia n.3 del 14 de enero de 2010, declaró la inconstitucionalidad de la disposición que disponía que se perfeccionaba la notificación enviando la carta certificada, y no en lugar de con la recepción de la misma o, en todo caso, 10 días después.

En Alemania, si no es posible la entrega a uno de los receptores subsidiarios previstos en el §178 I núm. 1 y 2 ZPO puede dejarse la notificación en el buzón, considerando practicada la notificación en ese momento ( $\$ 180 \mathrm{ZPO})$. Si tampoco puede practicarse la notificación según el §180 ZPO — por ejemplo, por no haber buzón—, el documento puede ser depositado en el registro del Amtsgericht que tenga jurisdicción en el lugar donde deba practicarse la notificación. En el caso de que la notificación sea practicada por servicio postal, el documento a notificar se depositaría en la oficina de correos del lugar donde deba practicarse la notificación o del Amtsgericht que tenga jurisdicción. A continuación, se enviará por escrito un aviso de dicho depósito a la dirección del destinatario o, sino fuera posible, se colocará un aviso en la puerta de su domicilio, oficina comercial o institución. Cuando dicho aviso haya sido enviado, la notificación se considera practicada (§181 ZPO). El documento se conservará durante tres meses para ser recogido y si no es recogido en dicho plazo, será devuelto al remitente (§181 II ZPO).

${ }^{74}$ Informe de la Comisión al Parlamento Europeo, al Consejo y al Comité Económico y Social Europeo sobre la aplicación
} 
En este mismo informe, aunque el RPME prevé el uso de medios electrónicos, la Comisión lamenta que no se estén empleando ${ }^{75}$. El uso de los medios electrónicos viene limitado por la legislación nacional del Estado en el que debe practicarse la notificación y, en el caso de notificación transfronteriza, el Reglamento (CE) 1393/2007 del Parlamento Europeo y del Consejo, de 13 de noviembre de 2007, relativo a la notificación y al traslado en los Estados miembros de documentos judiciales y extrajudiciales en materia civil o mercantil (en adelante, RN), ni tan siquiera permite la notificación electrónica directa, es decir, del órgano jurisdiccional del Estado de origen a un demandado en otro Estado miembro. La Comisión advertía, también, de otros problemas técnicos y de posibles incompatibilidades entre sistemas nacionales de notificación electrónica que no permiten una notificación de carácter transfronterizo. Si bien el Reglamento (UE) 2015/2421 del Parlamento Europeo y del Consejo, de 16 de diciembre de 2015, modificó tanto el RPEEC y el RPME, solo el primero fue reformado en este sentido, apostando por la notificación electrónica. Tal vez, el RPEEC funcione como banco de pruebas en esta materia y, si los resultados son satisfactorios, también se implementen las modificaciones correspondientes en el RPME. Además, en cuanto a la notificación transfronteriza, hay que tener presente la propuesta de modificación del RN que se está tramitando ${ }^{76}$, la cual posibilita la notificación electrónica transfronteriza.

El RPEEC, en su art. 13, preveía que las notificaciones se realizaran por correo con acuse de recibo. En caso de que no fuera posible realizar la notificación por correo con acuse de recibo, se preveía como regla subsidiaria el recurso a los medios de notificación previstos en los artículos 13 o 14 del RTEE — si bien los del art. 13 del TEE ya son con acuse de recibo-. Sin embargo, el Reglamento (UE) 2015/2421, de 16 de diciembre de 2015, que reformó los procesos europeos de escasa cuantía y monitorio, con respecto al de escasa cuantía, estableció ciertas novedades en el régimen de notificaciones. La reforma apostó con firmeza por la notificación electrónica ${ }^{77}$, equiparando ésta a la notificación por correo postal para la notificación de la demanda, reconvención y sentencia, exigiendo a ambas los mismos requisitos: acuse de recibo y constancia de la fecha de recepción ${ }^{78}$. Con respecto a la notificación por vía electrónica, se exige, por una parte, que los medios electrónicos sean una técnica prevista y admisible según el derecho nacional del EM en el que se sustancie el PEEC y en el caso de que el destinatario de la notificación tenga su domicilio o residencia habitual en otro Estado miembro según el derecho nacional de dicho Estado; y, por otra, que el destinatario haya consentido expresamente este medio de notificación ${ }^{79} \mathrm{o}$ que las disposiciones procesales del EM donde esté domiciliado o resida habitualmente le impongan el uso de dicho medio de notificación.

\section{B) Comparación con la notificación de requerimientos de pago nacionales}

41. Si acudimos a la comparación con algunos procesos monitorios nacionales, vemos que la situación es muy diversa.

42. En España, se ha considerado que en un proceso como el monitorio, donde se produce una inversión del contradictorio -implicando la incomparecencia del deudor, directamente, la emisión de

\footnotetext{
del Reglamento (CE) nº 1896/2006 del Parlamento Europeo y del Consejo por el que se establece un proceso monitorio europeo Bruselas, 13.10.2015 COM (2015) 495 final, p. 7.

${ }^{75}$ Ibidem, pp. 7 y 8.

${ }^{76}$ Propuesta de Reglamento del Parlamento Europeo y del Consejo por el que se modifica el Reglamento (CE) n. ${ }^{\circ} 1393 / 2007$ del Parlamento Europeo y del Consejo, relativo a la notificación y al traslado en los Estados miembros de documentos judiciales y extrajudiciales en materia civil o mercantil («notificación y traslado de documentos») Bruselas, 31.5.2018, COM(2018) 379 final, y la Resolución legislativa del Parlamento Europeo, de 13 de febrero de 2019, sobre la propuesta de Reglamento del Parlamento Europeo y del Consejo por el que se modifica el Reglamento (CE) n. ${ }^{\circ}$ 1393/2007 del Parlamento Europeo y del Consejo, relativo a la notificación y al traslado en los Estados miembros de documentos judiciales y extrajudiciales en materia civil o mercantil («notificación y traslado de documentos») (COM(2018)0379 - C8-0243/2018 - 2018/0204(COD)).

77 Vid. considerando 8.

78 Vid. considerando 10.

79 Vid. considerando 9.
} 
un título ejecutivo contra él— ${ }^{80}$, deben extremarse las garantías para poner en conocimiento del deudor la incoación de éste contra él. Por este motivo, el requerimiento de pago solo puede ser notificado a través de entrega personal por funcionario o procurador ${ }^{81}$.

43. En cambio, en Italia, la notificación del decreto ingiuntivo se notifica de acuerdo con las normas generales de notificación del atto introduttivo de cualquier proceso ordinario ${ }^{82}$, por lo que puede incoarse un proceso monitorio contra personas con domicilio desconocido o ilocalizables en el domicilio que se conoce, pudiéndose, así, notificar un requerimiento de pago a través de notificaciones ficticias.

44. En el caso del Mahnverfahren alemán, si bien los modos de notificación del Zahlungsbefehl no son tan restringidos como en el caso español, tampoco son tan amplios como en Italia. El proceso monitorio alemán tiene dos fases — característica propia de los procesos monitorios puros ${ }^{83}$ - Una primera en la que se le notifica el Mahnsbescheid al demandado indicándole que tiene un plazo para formular oposición (Widerspruch), ya que si no hubiera tal oposición — ni pago- se declararía la ejecutabilidad provisional de la orden de pago, considerándose ésta equivalente a una sentencia dictada en rebeldía. Entonces, se notifica un aviso de tal ejecución (Vollstreckungsbecheid) ${ }^{84}$ frente a la cual puede formularse de nuevo oposición (Einspruch), siguiéndose, en su caso, el cauce ordinario de oposición previsto para las sentencias dictadas en rebeldía; si no hubiera tal oposición, el título ejecutivo ya ostentaría carácter definitivo. La única restricción de los modos de notificación permitidos ${ }^{85}$ es la prohibición de la emisión del requerimiento de pago cuando el domicilio es desconocido — vetándose, de este modo, la notificación a través de la publicación de edictos - ${ }^{86}$; sin embargo, esta limitación se refiere a la notificación del Mahnsbescheid, no a la del Vollstreckungsbescheid ${ }^{87}$.

\section{C) Conclusiones}

45. La posibilidad de formular oposición y, por lo tanto, de ejercer el derecho de defensa depende de la efectiva notificación del requerimiento de pago. Las consecuencias de la incomparecencia del demandado son mucho más gravosas en un proceso monitorio, pues al invertirse el contradictorio, se obtiene un título ejecutivo con efectos de cosa juzgada de forma rapidísima, lo que implica que con la sola afirmación del acreedor de la existencia de un crédito a su favor éste obtiene una resolución favorable. De ahí que consideremos que el régimen de notificación de un requerimiento de pago deba ser más garantista que el previsto para un proceso ordinario.

46. Las normas de notificación del RPME, realmente, armonizan más bien poco, ya que parece que se optó por dar cabida a casi todos lo métodos de notificación posibles - de manera que los diversos Estados miembros no tuvieran que adaptar sus legislaciones procesales-.

\footnotetext{
${ }^{80}$ Además, hay que tener presente que la emisión del requerimiento de pago se basa, tan solo, en un principio de prueba, no en prueba plena.

${ }^{81} \mathrm{Vid}$. art. 815.1 párrafo segundo y art. 161 LEC. La Ley 13/2009, de 3 de noviembre, de reforma de la legislación procesal para la implantación de la nueva Oficina judicial, modificó el párrafo segundo del art. 815.1 LEC para declarar expresamente que el demandado no puede ser notificado a través de edictos salvo en el supuesto de impago de cantidades debidas en concepto de gastos comunes de comunidades de propietarios de inmuebles urbanos. Sin embargo, anteriormente ya se sostenía que no debía poderse, vid. J. López SÁnchez, El proceso monitorio, La Ley, Madrid, 2000, pp. 200 a 202, y I. Dízz Picazo Giménez, Comentarios a la Ley de Enjuiciamiento Civil (con A. De la Oliva; J. Vegas; y J. BanaCloche), Aranzadi, Madrid, 2001, p. 1367.

${ }^{82}$ Art. 643 en relación con arts. 137 y ss. Codice di procedura civile.

${ }^{83}$ De hecho, en la Propuesta de RPME se proyectaba un proceso monitorio europeo de dos fases (con un aviso europeo de pago y un posterior requerimiento de pago).

${ }^{84} \S 699$ I ZPO.

${ }^{85}$ Disposición especial para el caso de notificaciones al extranjero ( $\$ 688$ III ZPO).

86 § 688 II núm. 3 ZPO.

$87 \S 699$ IV ZPO.
} 
47. Sin pretender ofrecer un régimen de notificaciones totalmente distinto, creemos que el legislador europeo podría introducir algunas modificaciones.

48. En particular, creemos que se debería establecer una jerarquía, diferenciando entre modos de notificación principales y subsidiarios, para evitar que se pueda acudir directamente a un modo que ofrezca pocas garantías. También consideramos que podría ser interesante exigir un mínimo de intentos recurriendo a un método principal para evitar que se acuda directamente al método subsidiario. Así, nos parece razonable exigir un segundo intento con un método principal cuando el primero resultase infructuoso (por ejemplo, en el caso de notificación a través de entrega personal en la que no se encontrase a nadie a quién poder entregarle la comunicación, habría que realizar otro intento y, si éste fuese fallido, luego, se podría dejar un aviso en el buzón para que el demandado recogiese la comunicación en la oficina de correos o juzgado correspondiente) ${ }^{88}$.

49. Además, suprimiríamos la posibilidad de notificar el requerimiento europeo de pago a través de su depósito en el buzón del demandado. Únicamente mantendríamos la notificación por correo sin acuse de recibo del destinatario cuando ésta se practicara con acuse de recibo de un receptor subsidiario. La entrega a un receptor subsidiario, a través de entrega personal o por correo indistintamente, la incluiríamos en la categoría de principales porque creemos que ofrece un altísimo grado de probabilidad de que el documento notificado ha sido recibido por el destinatario. Y, finalmente, modificaríamos la regulación de la notificación electrónica tomando como referencia a la reciente modificación del RPEEC ${ }^{89}$.

${ }^{88}$ Con esto, pretendemos evitar, por ejemplo, que si en el primer intento no se halla a nadie en el domicilio ya se dejé, directamente, un aviso en el buzón. En esta línea, el Borrador inicial de la LEC introducía lo que consideramos una buena práctica o forma de proceder en materia de notificación: «Si el destinatario de la comunicación sí reside en ese domicilio, el Oficial se interesará de las horas en las que puedas ser localizado, y se repetirá el acto de comunicación». Vid., al respecto, C. SAMANES ARA, en Las partes en el proceso civil, La Ley Wolters Kluwer, Madrid, 2019, pág. 57.

${ }^{89}$ En síntesis, nuestra propuesta podría articularse así:

1. El requerimiento europeo de pago podrá notificarse al demandado de conformidad con alguna de las siguientes formas:

a) notificación personal acreditada por acuse de recibo, en el que conste la fecha de recepción, firmado por el demandado;

b) notificación personal acreditada por un documento, firmado por la persona competente que la haya realizado, en el que declare que el demandado recibió el documento o que se negó a recibirlo sin motivo legítimo y en el que conste la fecha de la notificación;

c) notificación por correo acreditada mediante acuse de recibo, en el que conste la fecha de recepción, firmado y reenviado por el demandado;

d) notificación personal o por correo con acuse de recibo, en el domicilio del demandado, a personas que vivan en la misma dirección que este, o que estén empleadas en ese lugar;

e) en caso de un demandado que sea trabajador por cuenta propia, o de una persona jurídica, notificación personal o por correo con acuse de recibo, en el establecimiento comercial del demandado, a personas empleadas por él;

f) notificación por medios electrónicos acreditada mediante acuse de recibo en el que conste la fecha de recepción:

i) cuando dichos medios estén disponibles técnicamente y sean admisibles con arreglo a las normas procesales del Estado miembro en el que se sustancie el proceso europeo de escasa cuantía y, en caso de que la parte destinataria de la notificación tenga su domicilio o residencia habitual en otro Estado miembro, con arreglo a las normas procesales de ese otro Estado miembro, $y$

ii) cuando la parte destinataria de la notificación haya dado previamente su consentimiento expreso a que los documentos se le notifiquen por medios electrónicos o cuando, con arreglo a las normas procesales del Estado miembro en que dicha parte esté domiciliada o resida habitualmente, esta tenga la obligación legal de aceptar ese medio concreto de notificación.

2. Cuando no sea posible proceder a la notificación de acuerdo con lo establecido en el apartado 1 tras un segundo intento, siempre que se conozca con certeza el domicilio del demandado, la notificación podrá realizarse de alguna de las siguientes formas:

a) depósito del requerimiento en una oficina de correos o ante las autoridades públicas competentes y notificación escrita de dicho depósito en el buzón del demandado, si en la notificación escrita consta claramente el carácter judicial del escrito o el hecho de que tiene como efecto jurídico hacer efectiva la notificación y, por tanto, constituir la fecha de inicio del cómputo de los plazos pertinentes.

b) por medios electrónicos con acuse de recibo acreditado mediante una confirmación automática de entrega, siempre que el demandado haya aceptado expresamente con anterioridad este medio de notificación. 


\section{El cauce de revisión en casos excepcionales del art. 20}

50. Como sabemos, el RPME, tras el transcurso del plazo ordinario para formular oposición, establece una vía de revisión para casos estrictamente excepcionales (art. 20). Visto que esta revisión tiene lugar una vez declarada la ejecutividad del requerimiento europeo de pago, ésta sería equiparable a lo que nosotros conocemos como medios de rescisión y nulidad de sentencias firmes ${ }^{90}$, de ahí que España haya comunicado ${ }^{91}$ que el cauce de revisión a seguir ante los tribunales españoles será el de rescisión de sentencias firmes a instancia del demandado rebelde (art. 501 y ss. LEC) en el supuesto del art. 20.1 o el incidente de nulidad de actuaciones del art. 241 LOPJ en el supuesto del art. 20.292.

51. La revisión en casos excepcionales prevista en RPME, en lo que se refiere a situaciones de rebeldía involuntaria (art. 20.1), es idéntica a la del artículo 19 del RTEE, mientras que el motivo previsto en el art. 20.2 parece que se inspira en el precepto relativo a la rectificación o revocación del certificado de título ejecutivo europeo (art. 10) ${ }^{93}$. Así, el demandado podrá plantear la revisión ante el órgano jurisdiccional competente del Estado miembro de origen siempre que: a) el requerimiento europeo de pago se hubiere notificado mediante una de las formas establecidas en el artículo 14 (es decir, sin acuse de recibo) y que la notificación no se hubiere efectuado con la suficiente antelación para permitirle organizar su defensa, sin que pueda imputársele responsabilidad por ello o b) el demandado no hubiere podido impugnar el crédito por razones de fuerza mayor o debido a circunstancias extraordinarias ajenas a su responsabilidad, siempre y cuando, en ambos casos, haya actuado con prontitud (art. 20.1). Otro motivo de revisión es la evidencia de que el requerimiento «se ha expedido de forma manifiestamente errónea, habida cuenta de los requisitos establecidos en el presente Reglamento, o por cualquier otra circunstancia de carácter excepcional» (art. 20.2) $)^{94}$. Todos los motivos de los que se pudiera tener

\footnotetext{
${ }^{90}$ L. Gómez Amigo, El Proceso..., op. cit., p. 118.

${ }^{91}$ Los Estados miembros tienen la obligación de comunicar a la Comisión el procedimiento de revisión a seguir en su Estado y los órganos jurisdiccionales competentes y cualquier modificación al respecto (art. 29.1.b).

${ }^{92}$ La STS 565/2015, de 9 de octubre, deja, también, la puerta abierta al recurso al proceso de revisión de los arts. 510 y ss. LEC para el caso de una maquinación fraudulenta del demandante dirigida a la ocultación del domicilio del demandado. Además, E. Vallines García, en «Proceso Monitorio Europeo: la revisión de un requerimiento de pago ejecutivo no procede cuando se basa en circunstancias que el demandado pudo haber tenido en cuenta para presentar un escrito de oposición», Cuadernos de Derecho Transnacional, Octubre 2017, Vol. 9, № 2, p. 728, añade que, también, cabría la posibilidad de interponer recurso de amparo ante el Tribunal Constitucional. En el caso de que en el plazo señalado no se haya formulado oposición o no se haya pagado la deuda, si el demandado tuviera conocimiento del monitorio incoado contra él, a pesar de que la notificación fuera defectuosa o de cualquier otra irregularidad, antes de que el Letrado de la Administración de Justicia dicte el decreto que pone fin al proceso monitorio y declara ejecutivo el requerimiento europeo de pago podría impugnarlo a través del recurso de revisión y, ante el eventual auto que lo desestimara, recurso de apelación.

93 S. García CANo, Estudios sobre el proceso monitorio europeo, Aranzadi, 2008, p. 212.

${ }_{94}$ En el caso de la STJUE de 22 de octubre de 2015, Thomas Cook Belgium, asunto C-245/14, el demandado no formuló oposición en los treinta días de plazo posteriores a la notificación del requerimiento de pago, a pesar de que la notificación se llevó a cabo de forma regular. Tampoco concurrió fuerza mayor ni ninguna otra circunstancia extraordinaria que le impidiera ejercer su defensa. No obstante, solicitó revisión del requerimiento europeo de pago según la vía prevista en el art. 20.2, alegando que éste había sido expedido «de forma manifiestamente errónea» al ser incompetentes los tribunales austriacos porque el contrato controvertido contenía una cláusula de sumisión expresa a los tribunales belgas. La cuestión prejudicial que se planteó, pues, pretendía dilucidar si el hecho de que el actor no mencionara en la petición de requerimiento europeo de pago el pacto de sumisión era motivo para considerar que el requerimiento se haya expedido de «forma manifiestamente errónea, habida cuenta de los requisitos establecidos en el presente Reglamento» o, en todo caso, se podría calificar esta como una circunstancia de carácter excepcional que debiera dar origen a la revisión del requerimiento.

Al respecto, el TJUE resolvió que el demandado debe plantear la incompetencia del tribunal dentro del plazo de oposición previsto por el art. 16. Así, esta cuestión compleja sería tratada de forma exhaustiva en el procedimiento civil al que diera lugar la oposición al requerimiento, ya que el examen de la petición está marcado por la nota de celeridad, intrínseca a la técnica monitoria (así, el art. 8 dispone que el órgano jurisdiccional ante el que se presenta la petición de requerimiento europeo de pago deberá examinarla «lo antes posible», concluyendo que «este examen podrá revestir la forma de un procedimiento automatizado»), por lo que no se puede concluir en ese momento procesal que el requerimiento europeo de pago se haya expedido de forma manifiestamente errónea.

Así, el TJUE concluye que el art. 20.2 RPME «debe interpretarse en el sentido de que se opone, en circunstancias como las del litigio principal, a que un demandado al que se haya notificado un requerimiento europeo de pago de conformidad con este Reglamento pueda solicitar la revisión de dicho requerimiento alegando que el órgano jurisdiccional de origen consideró erró-
} 
conocimiento con anterioridad a la expiración del plazo de treinta días del trámite de oposición, y si no ha habido impedimento alguno para que se pueda formular tal oposición -como el que pudiera suponer una notificación defectuosa (art. 20.1)-, deberán alegarse en ese trámite procesal. Por consiguiente, los motivos que no pudieron conocerse, siempre que no medie culpa por su parte, y, por lo tanto, no pudo plantearse la oposición ordinaria con base a los mismos, son aquellos que cabrían en las circunstancias excepcionales previstas en el apartado segundo del art. 20. Si se estima la revisión, el requerimiento europeo de pago será declarado nulo y sin efecto (art. 20.3).

52. Aunque éste sea un remedio excepcional y que, por lo tanto, se aplica de forma residual, es importantísimo porque permite —o debería permitir — subsanar una eventual situación de indefensión del demandado en un proceso monitorio europeo. Por esta cuestión, queremos poner el acento en una sentencia del TJUE que hace tambalear dicha vía de revisión.

53. La STJUE de 4 de septiembre de 2014, asuntos acumulados Eco Cosmetics (C-119/13) y Raiffeisenbank St. Georgen (C-120/13), versaba sobre dos supuestos de hecho en los que los respectivos requerimientos europeos de pago no se notificaron efectivamente a los deudores, ya que a pesar de haberse notificado, lo habían hecho en domicilios anteriores y no en el que residían en ese momento; sin embargo, en ambos casos, por falta de oposición, se declaró ejecutivo el requerimiento.

54. El TJUE declaró que la falta de notificación respetando el tenor de los artículos 13 a 15 provocó que los plazos de oposición pertinentes no empezaran a correr (art. 16 y 17), ya que el deudor no ha sido informado como es debido de la existencia del proceso. Por consiguiente, ni tuvo validez la declaración de ejecutividad (art. 18), ni la revisión en casos excepcionales del art. 20 se considera aplicable.

55. Además, el TJUE remarca que en la vía de revisión prevista en casos excepcionales del art. 20 no se prevé como motivo de revisión la falta de notificación ${ }^{95}$, ya que uno de los requisitos del art. 20.1 es que «el requerimiento de pago se hubiere notificado mediante una de las formas establecidas en el artículo 14»; lo que dejaría fuera del alcance de este precepto los supuestos de notificación irregular o, incluso, la falta de ésta. Tampoco que este supuesto pueda impugnarse a través del art. 20.2, es decir, porque el requerimiento se ha expedido de forma manifiestamente errónea, habida cuenta de los requisitos establecidos en el Reglamento, o por cualquier otra circunstancia de carácter excepciona ${ }^{96}$.

56. El TJUE no permite que opere el art. 20 en el caso de que se notifique el requerimiento sin respetar las normas mínimas de los arts. 13 a 15. Por lo tanto, si éstas no son aplicables, los deudores deberán impugnar dicha irregularidad de acuerdo con las vías previstas en el Derecho nacional (art. 26). Como sucede en los dos supuestos que subyacen a la sentencia, si la irregularidad en la notificación se manifiesta con posterioridad a la declaración de fuerza ejecutiva de un requerimiento europeo de pago, no le queda otra opción al demandado que recurrir a las vías de impugnación previstas en el Derecho nacional para la impugnación de resoluciones judiciales firmes ${ }^{97}$. Entonces, el TJUE concluye que cuando una irregularidad de tal magnitud vea la luz después de la declaración de ejecutividad de un requerimiento europeo de pago, no se aplica el Reglamento, pero el demandado debe tener la posibilidad de denunciar esa irregularidad mediante un cauce interno y que, si se demuestra tal irregularidad, se declare la invalidez de la fuerza ejecutiva del requerimiento europeo de pago.

\footnotetext{
neamente que era competente sobre la base de la información supuestamente falsa facilitada por el demandante en el formulario de petición del referido requerimiento de pago».

${ }_{95}$ Apartado 44.

${ }^{96}$ Considerando 25: «...Las demás circunstancias excepcionales a que se refiere el artículo 20, apartado 2, podrían incluir el hecho de que el requerimiento europeo de pago se hubiera basado en información falsa contenida en el formulario de petición».

${ }^{97}$ Vid. apartados 41 a 49.
} 
57. De la sentencia del Tribunal de Justicia en los asuntos C-119/13 y C-120/13 se desprende que un elemento fundamental de la protección de los derechos de la defensa en el proceso monitorio europeo, a saber, el derecho del demandado a solicitar una revisión de la resolución del art. 20, no es aplicable cuando a pesar de haberse emitido un requerimiento europeo de pago, la notificación no ha respetado las normas mínimas del reglamento (arts. 13 a 15), es decir, en los supuestos de notificación irregular o, incluso, cuando no ha habido notificación alguna. En estos supuestos, la solución dependería del Derecho nacional (art. 26). En síntesis, la revisión del art. 20 se limita a los supuestos en los que habiéndose practicado la notificación respetando lo dispuesto por el art. 14, el demandado la hubiere recibido tardíamente -por lo que no hubiera tenido tiempo de organizar su defensa- o la impugnación hubiere devenido imposible por razones de fuerza mayor o debido a circunstancias extraordinarias ajenas a su responsabilidad.

58. Nos posicionamos totalmente en contra de esta interpretación restrictiva que no permite la revisión mediante el instrumento del art. 20 ante la irregularidad de la notificación o la falta de ésta que hubiere impedido al demandado defenderse, porque cuando sucede esto es cuando es más necesario un cauce de recisión como el previsto en el art. 20. Además, consideramos que podría mejorarse la redacción del apartado 20.2, ya que no queda claro que cabe en referencia a cualquier otra circunstancia de carácter excepcional. Así, el propio considerando 25 es muy ambiguo y, tan solo, da un ejemplo de lo que podría incluirse en ellas: «[1]as demás circunstancias excepcionales a que se refiere el artículo 20, apartado 2, podrían incluir el hecho de que el requerimiento europeo de pago se hubiera basado en información falsa contenida en el formulario de petición».

59. Otra muestra de la configuración problemática del art. 20 la encontramos en el asunto Cat$\operatorname{lin}^{98}$. Ante la falta de información al requerido del derecho a negarse a aceptar el documento y la omisión de entrega del formulario del anexo II del RN, considera el TJUE que tal irregularidad en la notificación implica que el requerimiento europeo de pago no ha adquirido fuerza ejecutiva, por lo que el plazo otorgado al demandado para formular oposición ni tan siquiera se ha iniciado ${ }^{99}$; de ahí que la vía que había utilizado el demandado para impugnar tal irregularidad, a través del art. 20, concretamente aduciendo que la imposibilidad de entender el documento constituía una circunstancia excepcional en el sentido del art. 20.2, resulta inaplicable.

60. Uno de los aspectos que ha alcanzado la reforma del RPEEC realizada por el Reglamento 2015/2421, entre otros, es el relativo a la revisión de la sentencia en casos excepcionales (art. 18). El precepto sigue configurando unas condiciones mínimas, ya que el cauce procesal, remedio o vía de recurso se concreta a través del Derecho nacional. Sin embargo, la reforma muestra la voluntad del legislador europeo de ir un paso más allá, y no solo por la mayor armonización que implica la nueva redacción del precepto, sino que, incluso, a efectos simbólicos, en la rúbrica se elimina la consideración de normas mínimas.

61. Ahora, se establece que el demandado no comparecido tendrá derecho a solicitar una "revisión" de la sentencia cuando a) no se le hubiese notificado el formulario de demanda o, en el caso de una vista oral, no se le hubiese citado a ésta en tiempo oportuno y de forma que le permitiese preparar su defensa, o b) le hubiese resultado imposible contestar a la demanda por causa de fuerza mayor o circunstancias extraordinarias ajenas a su responsabilidad.

62. Antes se exigía que el demandado hubiera actuado con prontitud, ahora que el demandado haya recurrido la sentencia cuando hubiera podido hacerlo. Este cambio solo viene a clarificar lo que ya se entendió en su momento por "actuar con prontitud", es decir, que el demandado, una vez tenga

\footnotetext{
${ }^{98}$ STJUE de 6 de septiembre de 2018, Catlin, asunto C-21/17.

${ }^{99}$ Apartado 53.
} 
conocimiento del proceso incoado contra él, aproveche la primera oportunidad procesal disponible para impugnar y, así, reparar la indefensión sufrida ${ }^{100}$.

63. La reforma, en aras de una armonización mayor, establece un plazo de 30 días para solicitar la revisión (art. 18.2); cuestión que antes dependía de lo dispuesto para el concreto cauce de impugnación al que se recurriera según el Derecho nacional. El dies a quo de dicho plazo empieza a computar «desde la fecha en que el demandado tuvo efectivamente conocimiento del contenido de la sentencia y pudo reaccionar», especificando que se entenderá que ha tenido efectivo conocimiento del contenido de la sentencia, lógicamente, «a más tardar desde la fecha de la primera medida de ejecución que tenga por efecto la inalienabilidad de los bienes del demandado, en su totalidad o en parte». Finalmente, se establece que dicho plazo será improrrogable.

64. Si la revisión es rechazada por no cumplir con los motivos requeridos en tal precepto, la sentencia se considerará firme (art. 18.3). Si la revisión se considera justificada, la sentencia será “declarada nula de pleno derecho"; introduciendo explícitamente la reforma que el demandante «conservará el beneficio de cualquier interrupción de los plazos de prescripción o caducidad cuando sea de aplicación tal interrupción de acuerdo con la normativa nacional».

65. La reforma viene claramente inspirada por el art. 19 del Reglamento (CE) $n^{\circ}$ 4/2009 relativo a la competencia, la ley aplicable, el reconocimiento y la ejecución de las resoluciones y la cooperación en materia de obligaciones de alimentos (RB III). De hecho, ambos artículos son idénticos salvo en el plazo (30 y 45 días) y que, con respecto a la conservación del beneficio a la interrupción o suspensión de los plazos de prescripción o caducidad, el RB III va un paso más allá en su armonización, ya que dicho beneficio es aplicable independientemente de lo dispuesto por el concreto derecho nacional.

66. Y volviendo a lo que nos interesa, creemos que el artículo 20.1 del RPME debería ser modificado en igual sentido que el art. 18 del RPEEC, ya que así tendríamos una revisión sin restricciones absurdas que dieran lugar a casos como el de Eco Cosmetics y Raiffeisenbank St. Georgen y no dejaríamos al albur de los derechos nacionales una cuestión - la del remedio frente a situaciones de indefensión causadas por vicios procesales advertidos después de que el requerimiento europeo de pago haya adquirido fuerza ejecutiva - a la que debe dar solución el propio RPME.

\section{Lenguas aceptables en el Estado miembro de ejecución}

67. En caso de que el requerimiento europeo de pago deba ser notificado en otro Estado miembro resultará de aplicación el RN, por lo que, de acuerdo con el artículo 8 de este último, deberá informarse al demandado a través del formulario normalizado del anexo II de su derecho a negarse a aceptar el requerimiento si éste no estuviera redactado o acompañado de una traducción en una lengua que el destinatario entienda o bien una lengua oficial del Estado miembro requerido.

68. Pero dejando de lado este aspecto, ahora nos queremos referir a la cuestión idiomática del art. 21. En este, tras declarar que la ejecución se regirá por el Derecho del Estado miembro de ejecución, dispone que el demandante deberá presentar, además de una copia del requerimiento europeo de pago, si fuera necesario, «una traducción del requerimiento europeo de pago a la lengua oficial del Estado miembro de ejecución o, en caso de que dicho Estado miembro tenga varias lenguas oficiales, a la lengua oficial o a una de las lenguas oficiales de los procedimientos judiciales en el lugar en que deba ejecutarse, conforme al Derecho de dicho Estado miembro, o a otra lengua que el Estado miembro de ejecución

${ }^{100}$ F. GASCÓN InChausti, «Artículo 18: Normas mínimas para la revisión de la sentencia», El proceso europeo de escasa cuantía (coords. F López Simó y F. Garau Sobrino), Dykinson, Madrid, 2010, p. 287. 
haya indicado como aceptable» (art. 21.2.b). Se añade como requisito que la traducción sea «certificada por una persona cualificada para ello en uno de los Estados miembros» ${ }^{101}$.

69. Como hemos señalado, «cada Estado miembro podrá indicar la lengua o lenguas oficiales de las instituciones de la Unión Europea distintas de las propias que pueda aceptar para el requerimiento europeo de pago»; sin embargo, pocos países aceptan lenguas distintas de las propias. Así, por ejemplo, España, Italia y Alemania solo aceptan las propias ${ }^{102}$. En cambio, Francia acepta, también, el inglés, el alemán, el español y el italiano. Por ello, simplemente, queríamos abogar por la tendencia seguida en Francia, ya que ello contribuye a disminuir los costes y la duración del proceso provocados por la necesidad de traducciones y, lo que es muy importante también, a vencer los recelos propios del litigante extranjero.

\section{Consideraciones finales}

70. En España, en el año 2018, se incoaron un total de 576.846 procesos monitorios. La importancia del proceso monitorio es irrefutable, ya que los monitorios representaron el $43.5 \%$ del total de procesos contenciosos iniciados. De estos procesos monitorios, 5884 fueron europeos $(1,03 \%$ del total $)^{103}$. Un 7,4\% de los procesos monitorios terminaron en pago, 213.689 concluyeron transcurrido el plazo sin que se formulase oposición y 34.910 se transformaron en juicios verbales y 11.406 en ordinarios. El 45,7\% terminó debido a la inadmisión de la petición, por imposibilidad de encontrar al deudor o por falta de competencia del juzgado ante el que se presentó la solicitud ${ }^{104}$.

71. Creemos que es hora de dotar de fuerza a algún proceso europeo uniforme porque, aunque la repercusión política - y académica — ha sido grande, la verdad es que la relevancia práctica del TEE, el PME y el PEEC ha sido más bien poca ${ }^{105}$. Y no será porque el sustrato sea pobre: según datos de la Comisión Europea, en el año 2013, el comercio transfronterizo entre países de la UE fue de 2,8 billones de euros y, según un informe encargado por la misma $\mathrm{CE}^{106}$, en el año 2018 hubo unos 3,4 millones de litigios civiles o mercantiles con implicaciones transfronterizas. El problema es que existe un gran desconocimiento de estos instrumentos entre los diversos operadores jurídicos, por lo que, sin perjuicio de más formación y difusión, una extensión del ámbito de aplicación a lo puramente interno podría redundar en un mayor conocimiento del instrumento y, por ende, incluso, en un mayor aprovechamiento

${ }^{101}$ También podría reconsiderarse tal exigencia, ya que, por ejemplo, si se ha recurrido a un abogado que tiene una competencia profesional completa en la lengua que se requiera, obligar a acudir a un traductor o intérprete supondría incrementar los costes innecesariamente.

${ }^{102}$ Pueden verse las lenguas aceptadas, conforme al artículo 21.2.b, de los diversos países en el Atlas Judicial Europeo en materia civil (https://e-justice.europa.eu/content_european_payment_order-353-es.do?clang=es).

${ }^{103}$ Mientras que en el año 2013 se iniciaron 996 procesos monitorios europeos. Vid. la Memoria sobre el estado, funcionamiento y actividades del Consejo General del Poder Judicial y de los juzgados y tribunales en el año 2013, p. 474.

${ }^{104}$ Datos extraídos de la Memoria sobre el estado, funcionamiento y actividades del Consejo General del Poder Judicial y de los juzgados y tribunales en el año 2018, p. 356.

105 En E. Alina OnTANU, «Incorporating European Uniform Procedures into National Procedural Systems and Practice: Best Practices a Solution for Harmonious Application», en Hess, B., y KRAMER, X. E. (eds.), From common rules to best practices in European Civil Procedure, Nomos, Baden-Baden, 2017, p. 472, pueden encontrarse datos sobre la aplicación del PME y el PEEC hasta 2014 en Inglaterra y Gales, Francia, Italia y Rumania, los cuales son, al igual que los de España, muy bajos. En más profundidad, de la misma autora, vid. Cross-Border Debt Recovery in the EU. A Comparative and Empirical Study on the Use of the European Uniform Procedures, Intersentia, Cambridge, 2018.

El instrumento que tiene gran relevancia práctica es el RB I bis —igual que la tuvo, también, su antecesor-, ya que se acude al proceso nacional ordinario que corresponda y, luego, si es necesaria, la ejecución de la resolución en otro EM se realiza al amparo de este reglamento.

${ }^{106}$ Estudio económico realizado por Deloitte (JUST/2017/JCOO/FW/CIVI/0087). Este informe ha sido utilizado para la realización del Commission staff working document impact assessment accompanying the document Proposal for a Regulation of the European Parliament and of the Council amending Regulation (EC) No 1393/2007 of the European Parliament and of the Council on the service in the Member States of judicial and extrajudicial documents in civil or commercial matters (service of documents), p. 75, Bruselas, 31.5.2018 SWD (2018) 287 final. 
para lo transfronterizo. Si hay que apostar por un proceso realmente uniforme en el ámbito de la Unión Europea, éste debe ser el monitorio. Porque, por una parte, seguramente será el que tendrá un mayor impacto, del que se podrán beneficiar más justiciables; y, por otra, su simplicidad y ser el proceso donde hay menos divergencias, ya sea entre los mismos procesos monitorios nacionales o los nacionales y el europeo, hacen que sea el mejor candidato para que los ordenamientos procesales civiles nacionales puedan asumirlo de forma poco traumática.

72. Una extensión del ámbito de aplicación del proceso monitorio europeo más allá de los litigios transfronterizos, manteniendo su carácter opcional frente al proceso nacional, podría, incluso, ayudar no solo a una mejor aplicación del PME, sino que la competencia entre ambos procesos sacaría a relucir las ventajas e inconvenientes de uno y otro, ilustrando, así, al legislador sobre las best rules and practices en técnica monitoria.

73. En un escenario de cohabitación entre el proceso monitorio europeo y el nacional, veríamos que las diferencias existentes entre ellos harían decantarse a los acreedores por uno u otro. Dejando de lado el régimen privilegiado de ejecución transfronteriza del PME, veamos algunas de estas diferencias.

74. En el proceso monitorio europeo no se exige al demandado que motive su oposición (art. 16.3 RPME), en cambio, en España, se ha pasado de exigir una alegación sucinta de las razones de la oposición a una alegación fundada y motivada (art. 815.1 LEC). El motivo de esta reforma en España se halla en la adecuación del juicio verbal derivado de la oposición del deudor a la nueva estructura del mismo, exigiéndose tal motivación porque el escrito de oposición pasa a operar como escrito de contestación a la demanda (art. 818.2 LEC). Este es una de las razones por la cual el acreedor podría preferir optar por el monitorio español en lugar del europeo — si estos compartieran ámbito de aplicación— ${ }^{107}$. Sin embargo, tampoco pasarían inadvertidas las deficiencias que implica el nuevo sistema español de transformación del proceso monitorio en juicio verbal, que sin querer - ni poder - ahondar en ello en este trabajo ${ }^{108}$, tan solo pretendemos mostrar como ello afecta, también, a la debida armonización entre el proceso monitorio europeo y el juicio verbal. Imaginemos el siguiente supuesto. Se insta un proceso monitorio en España y, una vez emitido el requerimiento, el deudor formula oposición. El demandante no indicó que, en caso de oposición, el litigio continuara a través del proceso europeo de escasa cuantía. La cantidad reclamada es inferior a 6000 euros, por lo que corresponde que se tramite a través del juicio verbal. ¿Cómo va a servir de contestación a la demanda una oposición sin motivación (art. 16.3 RPME)?

75. En el PME no se exige representación por abogado u otro profesional del Derecho ni para la presentación de la petición inicial de requerimiento europeo de pago ni para formular oposición (art. 24 RPME) ${ }^{109}$. Mientras que en el monitorio español no es preceptiva la intervención de abogado y procurador para presentar la petición inicial, sí que lo es para formular oposición cuando la cuantía del requerimiento sea superior a 2000 euros (arts. 818.1; 23.2.1 ${ }^{\circ}$; y 31.2.1 ${ }^{\circ}$ LEC). Sin embargo, aunque en el PME la asistencia letrada no sea obligatoria, en la práctica se recurre a ella ${ }^{110}$; lo que puede deberse a una arraigada tradición al recurso al abogado para cualquier tipo de litigio — como sucede en Españao que las dificultades inherentes a la litigación transfronteriza llevan al litigante extranjero a preferir la

\footnotetext{
${ }^{107}$ Una oposición que resulte genérica o imprecisa comportaría la inadmisión de la misma.

${ }^{108}$ Nos remitimos al interesante análisis de la problemática realizado por J. F. Herrero Perezagua, en «Cinco preguntas sobre la transformación del monitorio», op. cit., pp. 38 a 40.

${ }^{109}$ Sin olvidar que, salvo lo dispuesto expresamente en el RPME, la ejecución se regirá por el Derecho del Estado miembro de ejecución (Art. 21.1 RPME). Así, en el caso español, «para la ejecución derivada de procesos monitorios en que no haya habido oposición, se requerirá la intervención de abogado y procurador siempre que la cantidad por la que se despache ejecución sea superior a 2000 euros» (539.1 LEC).

110 E. Alina OnTANU, «Incorporating European Uniform Procedures into National Procedural Systems and Practice: Best Practices a Solution for Harmonious Application», op. cit., pp. 466 y 467, y F. GASCón InCHAusti; M. ReQueJo IsIDRo, «A Classic cross-border Case: the Usual Situation in the First Instance», en B. Hess y P. Ortolani (eds.), Impediments of National Procedural Law to the Free Movement of Judgments. Luxembourg Report on European Procedural Law, Vol. I, C.H Beck; Hart; Nomos, Múnich, 2019, p. 45.
} 
asistencia de un abogado. Esto tiene una evidente repercusión en las costas, ya que si la intervención de abogado no es preceptiva, su coste no es incluible en las mismas, por lo que dichos gastos son irrecuperables (arts. 32.5 y 241.1.1 ${ }^{\circ}$ LEC). Por este motivo, tal vez, el legislador europeo tendría que reconsiderar su apuesta contraria a la intervención preceptiva de abogado - que, aun cuando con potentes argumentos a su favor, no ha conseguido tener éxito en la práctica-o, al menos, si no se quiere imponer tal obligación, podría buscar una vía para que la parte vencedora pueda recuperar dichos honorarios -o parte de ellos- $-^{111}$.

76. A la vista de todo lo expuesto en este trabajo, para concluir quiero remarcar que no creemos que la creación de un proceso monitorio europeo que alcance, también, los litigios internos sea la panacea. Reconocemos que, por lo menos en un primer momento, algunos de los posibles beneficios de la opción que proponemos serían difícilmente tangibles; como podría ser la facilitación del acceso a la justicia en las mismas condiciones en todo el espacio europeo, lo que coadyuvaría a la cohesión y mejor funcionamiento del mercado interior y del espacio de justicia de la UE. Sin embargo, al mismo tiempo, estamos seguros de que ello no causaría estragos. Por este motivo, abogamos por que se tome esta propuesta como una oportunidad para mejorar la calidad de la tutela judicial del crédito a través de la técnica monitoria en el ámbito europeo.

${ }^{111}$ Vid. F. Gascón Inchausti; M. RequeJo Isidro, «A Classic cross-border Case: the Usual Situation in the First Instance», op. cit., p. 45. 